\title{
Hotspot Concept: The French Polynesia Complexity
}

\author{
Claudia Adam \\ CGE/Univ. Evora \\ Portugal
}

\section{Introduction}

At the surface of the Earth, volcanism is found in several tectonic contexts. It is largely concentrated at the plate margins: at divergent plate boundaries, mid-oceanic ridges, where new tectonic plates are created, and at convergent margins, subduction zones, where the lithospheric plates dive into the mantle. In the interior of the oceanic plates, we find however linear volcanic chains, composed of several volcanoes aligned along the direction of the plate motion. Their origin has been attributed to the drifting of the lithospheric plates over a fixed, hot mantle upwelling, deeply rooted in the mantle. Since several years, this concept is debated and the existence of the plumes themselves is questioned.

Here we focus on French Polynesia, a region characterized by a great concentration of volcanism and situated on the South Pacific Superswell, a wide area associated with numerous geophysical anomalies, including anomalously shallow seafloor considering its age, a dip in the geoid, and a mantle characterized by slow seismic velocities. $14 \%$ of the active volcanism is concentrated in an area covering less than $5 \%$ of the globe. A wide range of volcanic features should be noted: en echelon ridges, isolated seamounts and chains of midplate volcanoes. The characteristics of these chains often depart from the classical definition of hotspots. In particular, the broad depth anomalies surrounding the chains, called swells, display peculiar morphologies. These characteristics are however well recovered by a numerical model based on highly resolved seismic tomography model, describing the first $240 \mathrm{~km}$ of the upper mantle. This demonstrates that a direct link exists between the surface observations and mantle flows. However, even if the dynamics of the shallowest part of the mantle is sufficient to explain the surface observations, the existence of the secondary plumes at the origin of the hotspot chains, cannot be accounted for without involving a deeper component: the South Pacific superplume. This latter displays a complex signature in tomography models where it appears as broad low velocity anomalies throughout the lower mantle up to $1000 \mathrm{~km}$, depth at which they split into narrower and more localized anomalies, a few hundred kilometers in diameter. Two of these narrow upwelling are associated with hotspots - the Society and Macdonald ones -, whereas the upwellings at the origin of the other chains seem to be restricted to the upper mantle. The pattern pointed out by the tomography is well retried by analogical experiments where two layers of miscible fluids are superimposed in a tank heated from below and cooled from above. In some conditions, long-lived thermochemical domes that oscillates vertically are produced. Experimentally, secondary plumes are observed at the top of the rising domes. 


\section{Hotspot concept}

Hotspot chains are chains of midplate volcanoes, surrounded by wide shallow regions, called swells. The chains are composed of several volcanoes, aligned along the direction of the tectonic plate motion. The age of volcanism increases linearly along the chain, and active volcanism is often found at one extremity of the chain. One of the most classical example of such chains is Hawaii. This pattern, partially observed hundreds of years ago, has fascinated people and several explanations for its origin have been proposed.

\subsection{First hypothesis on the origin of linear volcanic chains: ancient legends}

The notion of volcanism migration is even older than the plate tectonics theory. According to Hawaiian legends, the fuming Pele goddess get angry with her sister after a terrible quarrel and went south-east, building in her way Diamond head on the Oahu island, Haleakala on the Maui island and the Kilauea on Hawaii, where she is living now - the actual active extremity of the chain. Another explanation, points out to the Namazu giant carp, leaving beneath Japan, which would be responsible for the Mount Fuji eruption when it shifts position. An extrapolation of this Japanese legend, (Holden and Vogt, 1977), makes Namazu swimming in the mantle, leaving behind it a buoyant trail of tholeiitic bubbles, rising ponderously, and creating chains of midplate volcanoes (Fig. 1).

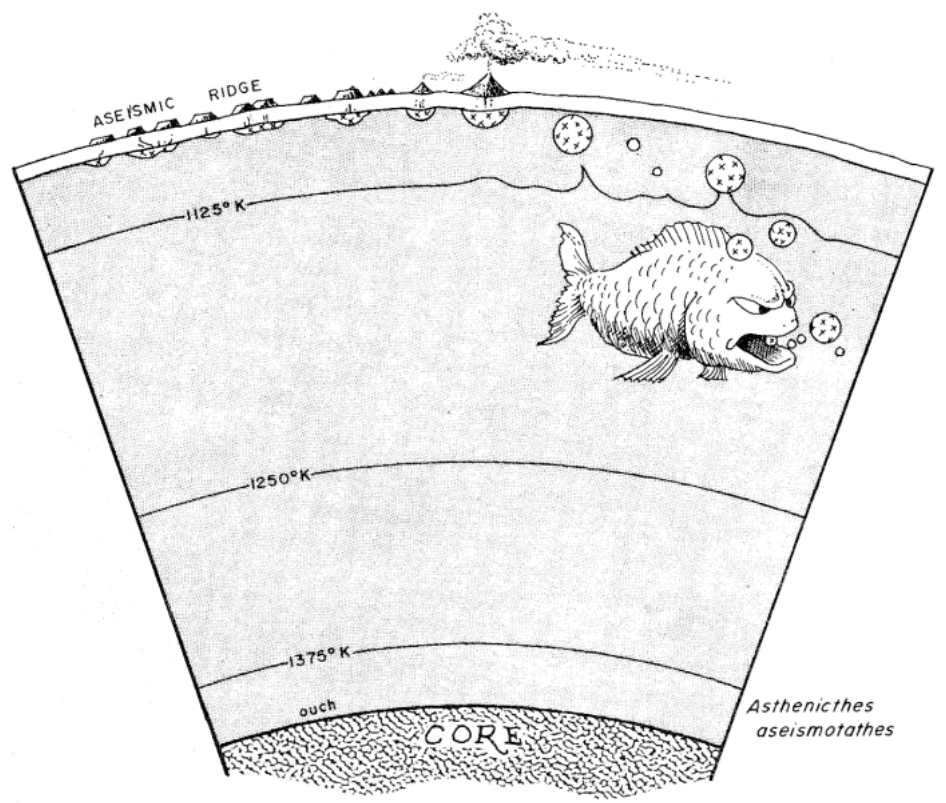

Fig. 1. Alternative to mantle plume theory (based on ancient Japanese legend), from Holden and Vogt (1977).

\subsection{The hotpot concept: Mantle plumes and plate tectonics}

More recently, the hotspot concept emerged at the same time that the plate tectonics theory (Wilson, 1963). As hotspot chains (Fig. 2) are linear volcanic alignments, parallel to the 
direction of the plate motion, and displaying regular volcanism age progression, with active volcanism emplaced at one extremity of the chain, Morgan $(1971,1972)$ proposes that the origin of these tracks may be due to deep mantle plumes. He imagines the plumes as vertical conduits through which hot mantle flows upward. The hotspot tracks are then due to the drifting of a plate over a stationary mantle source. The plate displacement pushes the old volcanoes away from the source as young volcanoes are formed above the source (Fig. 2).

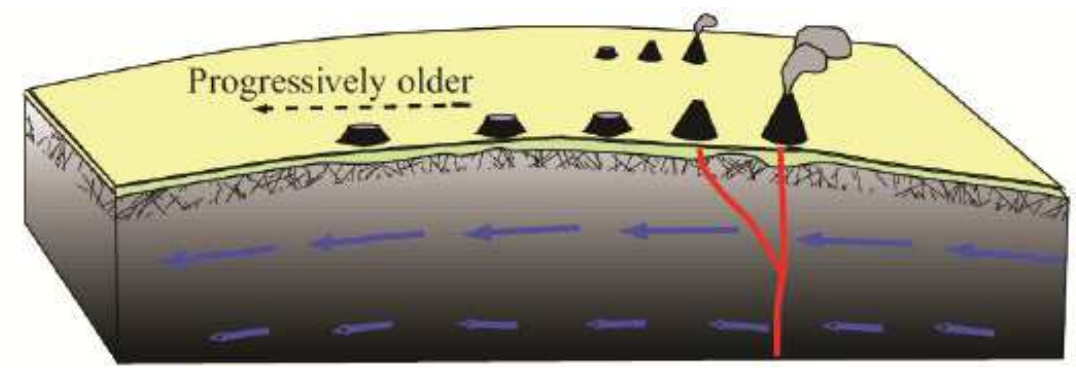

Fig. 2. The hotspot concept: the hotspot tracks are due to the drifting of a plate over a stationary mantle source. The plate displacement pushes the old volcanoes away from the source as young volcanoes are formed above the source- from Clouard (2001)

The plume itself would be characterized by a mushroom-shaped head and a thin, long stem. When the head of the plume reaches the lithosphere, it produces a massive volcanic event, and creates traps (or oceanic plateaus) at the surface. This episode is followed by the interaction of the stem with the lithosphere, which produces the linear volcanic chain.

\subsection{The plume debate}

The simple model of the interaction of a hot mantle upwelling, deeply rooted in the mantle, and the overriding lithosphere has since then been challenged, and the existence of plume is now questioned.

The characteristics which fuels the more energetically the 'plume debate' is the depth at which they initiate (Clouard \& Bonneville, 2001; Sleep, 1990; Anderson, 2000). From the fluid dynamics point of view, a plume can only initiate from instabilities out of a thermal boundary layer. Morgan $(1971,1972)$ proposes first that plumes initiate in the lower mantle, but later has an idea of a second type of hotspot (Morgan et al. 1978). Other authors invokes superficial sources which use the weakness zones of the lithosphere to express themselves at the surface (Turcotte \& Oxburgh, 1973; Anderson, 1975; Foulger et al., 2005; Foulger, 2010; Anderson, 2010). This last hypothesis, also called theory of Plate Tectonics Processes (PTP), points to a passive mantle. The volcanism emplacement would then be controlled by the stress field in the plate, and the magnitude of volcanism by the fertility of the underlying shallow mantle (Foulger et al., 2005; Foulger, 2010; Anderson, 2010). Higher mantle temperatures are not required in this case, and only the shallow part of the mantle is involved in the volcanism emplacement.

Geochemist have tried to answer this open question. Rocks from hotspot volcanoes (OIB: Ocean Island Basalts) appear indeed enriched in noble gazes when compared to Mid Oceanic Ridge Basalts (MORB). As mid-oceanic ridges sample a shallow part of the mantle, plumes must tap deep reservoirs, enriched in noble gazes, which remained isolated from 
intermixing. However, recent studies indicate that there is no need to invoke deep isolated reservoirs to account for the geochemical signatures of OIB (Anderson, 1998; Allègre, 2002). In then appears that "geochemistry will not deliver the silver bullet for proving or disproving plumes" (Hofmann \& Hart, 2007), neither discriminate the depth at which mantle upwellings initiate.

If the plumes at the origin of hotspots are hot mantle upwellings, they mantle beneath midplate chains should be characterized by anomalously low shear velocities (Vs). However, most of the available tomography models lack resolution at the scale of the plume, and therefore stems are not easily identifiable. Moreover, a low velocity anomaly does not unswervingly imply a hotter region, but could also be interpreted in terms of a chemical anomaly (Karato, 2008).

The morphology of the volcanic chain itself bring information about the plume dynamics. According to the classical definition, first proposed by Morgan $(1971,1972)$, there must be a flood basalt near the oldest extremity of the chain, and the linear chain should display a long and monotonous age progression. The swell surrounding the chain is a direct consequence of the buoyant plume upwelling, and therefore, is also commonly used as the parameter to quantify the hotspot strength (Sleep, 1990; Courtillot et al., 2003; Vidal \& Bonneville, 2004, Adam et al., 2005).

By analyzing the previously described criteria, Courtillot et al. (2003) show that three kind of plumes may coexist, each of them corresponding to a boundary between the CMB and the seafloor: those which initiate at the $\mathrm{CMB}$ (primary plumes or Wilson-Morgan), the secondary plumes initiating at the transition zone (also called secondary hot spots) and the "Andersonian" plumes that may be due to a passive response to forms of lithospheric breakup (Anderson, 2010; Foulger et al., 2005). According to their analysis, the primary (or Wilson-Morgan) hotspots in the Pacific may be Hawaii, Louisville and Eastern, and the secondary ones Caroline, Macdonald, Pitcairn, Samoa and Tahiti (see Fig. 3.) Let us now see in a more practical way which are the characteristics of hotspot chains, by considering what is happening in French Polynesia.

\section{French polynesia region}

\subsection{Description of the french polynesia volcanism}

This study focuses on the French Polynesia (Fig. 3, 4), a region particularly interesting for the study of intraplate volcanism. There is indeed a great concentration of volcanism: $14 \%$ of the active volcanism is concentrated in an area covering less than $5 \%$ of the globe. The young volcanoes (Fig. 4) in the region are the Macdonald (Norris \& Johnson, 1969) and Arago (Bonneville et al., 2002) seamounts in the Austral archipelago, Mehetia and Tehetia (Talandier and Okal, 1984) in the Society Islands, and Adams seamount (Stöffers et al., 1990) in the Pitcairn-Gambier alignment. A wide range of volcanic features should be noted: en echelon ridges, chains of midplate volcanoes and isolated seamounts. The five main chains in the region are the Society, the Marquesas, the Tuamotu, Pitcairn-Gambier and the CookAustral (Fig. 4). Their characteristics often depart from the classical definition of a hotspot chains, which accounts for the simple interaction of a mantle upwelling with the overriding lithosphere. The age progression in the volcanic chains is often short (0-4.2 Ma for the Society Islands (Duncan \& McDougall, 1976) and 0.5-6.0 Ma for the Marquesas (Desonie et al., 1993; Diraison, 1991)) and the orientation of the chains do not systematically correspond to the motion of the oceanic plate, like in the Marquesas where the chain is rotated $30^{\circ}$ 
clockwise from the direction of the absolute plate motion (Desonie et al., 1993). The lithosphere seems to exert a considerable influence on the location of the volcanism, like in the Austral Islands where two periods of linear volcanism, separated by 10 m.y., are superimposed on the same volcanic edifices (Bonneville et al., 2002). Let us see now, in more details, the characteristics of the main chains.
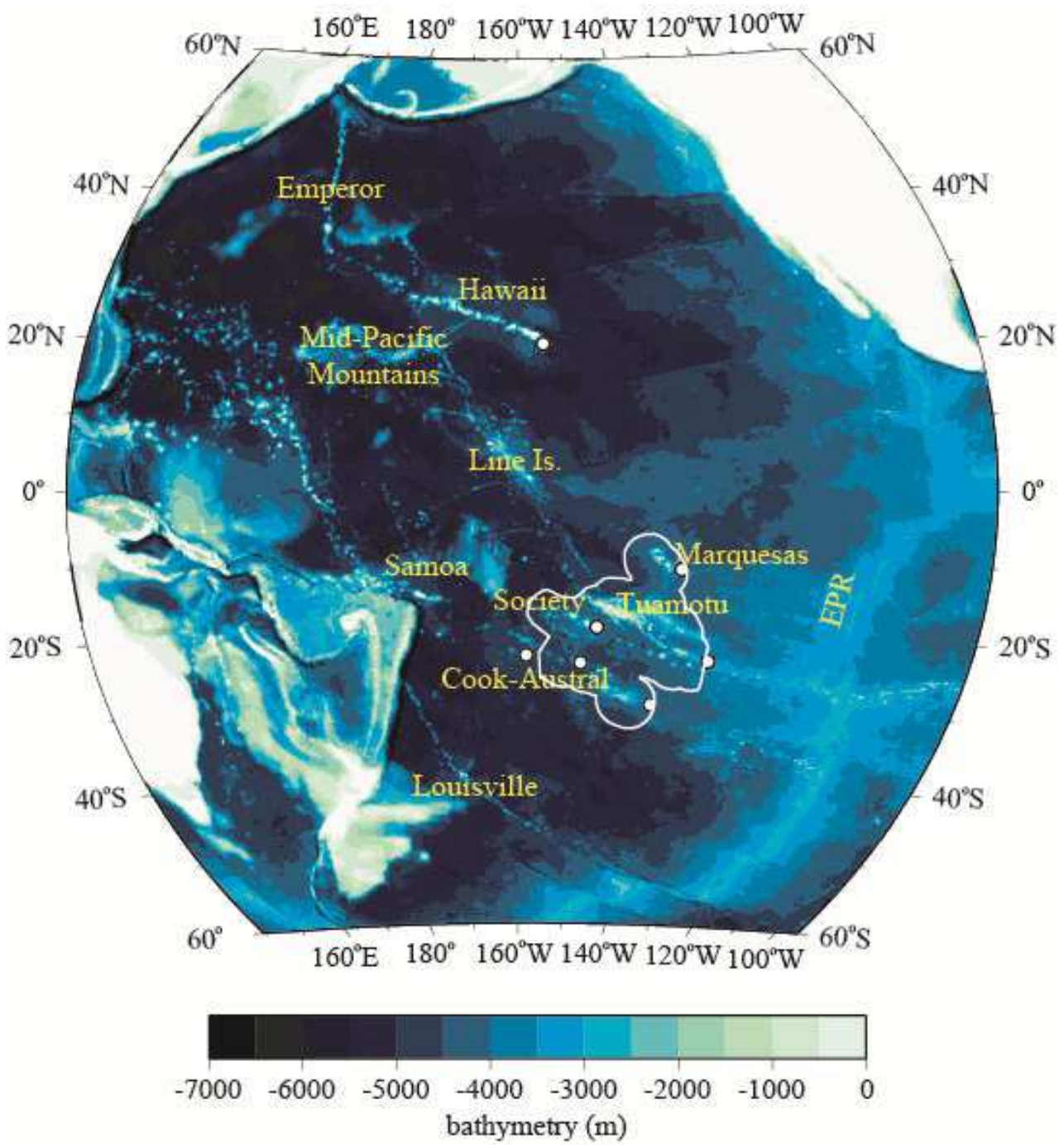

Fig. 3. Bathymetry of the Pacific, from Smith and Sandwell (1997). The names of the main volcanic chains are reported in yellow. The French Polynesia region is delimitated by the white contour. 


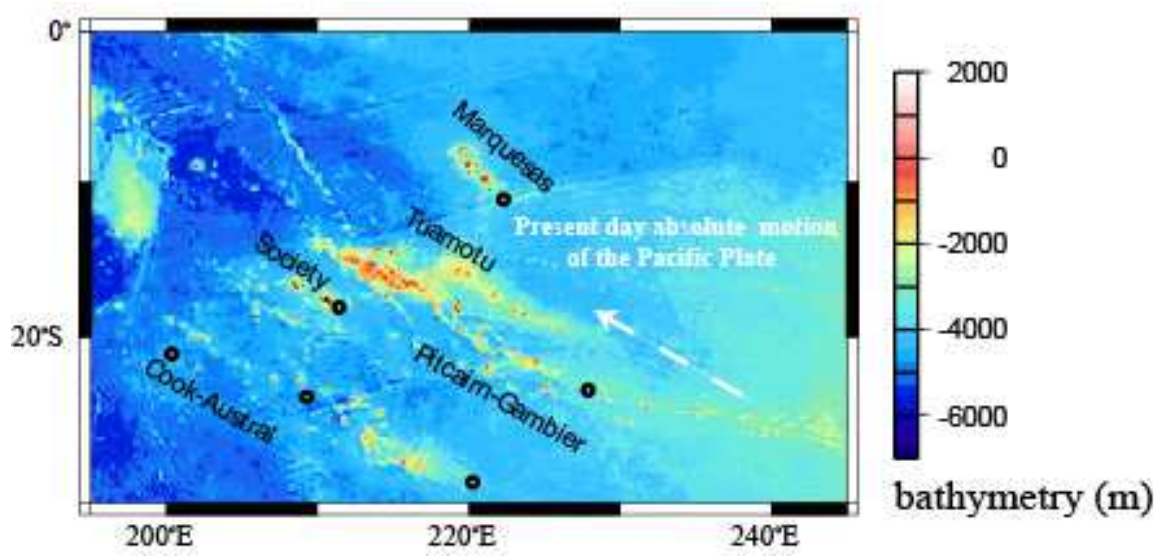

Fig. 4. Bathymetry of the French Polynesia region, obtained with Smith and Sandwell's [1997] grid. The names of the volcanic chains are reported. The disks represent the emplacement of young volcanism.

\subsubsection{Society}

The Society chain (Fig. 5) is the only classical case of hotspot in our study area. The Society islands are situated between latitudes $16^{\circ} \mathrm{S}$ and $19^{\circ} \mathrm{S}$ and longitudes $147^{\circ} \mathrm{W}$ and $153^{\circ} \mathrm{W}$ on a seafloor displaying ages between 65 and $95 \mathrm{Ma}$. They stretch along a 200-km-wide and 500$\mathrm{km}$-long band orientated in the direction of the present-day Pacific plate motion: N115 $\pm 15^{\circ}$. The age progression is uniform from the youngest submarine volcano, Mehetia [0.264 Ma (Duncan \& McDougall, 1976)], situated at the southeast extremity, to the oldest dated island, Maupiti [4.8 Ma (White \& Duncan, 1996)]. The topographic anomaly associated with this alignment (Fig. 5b) stretches along the volcanic chain. Its maximal amplitude, $980 \mathrm{~m}$, is reached $30 \mathrm{~km}$ northwest of Tahiti, and is not correlated with any volcanic structure. For this volcanic chain, the swell description corresponds to the one previously reported for hot spot swells: it stretches along the volcanic chain and subsides along the direction of the plate motion; the swell's maximum is located roughly 200 kilometers downstream from the active volcanism.

\subsubsection{Cook-Austral}

The Cook-Austral chains extend from the island of Aitutaki $\left(140^{\circ} \mathrm{W}, 29^{\circ} \mathrm{S}\right)$ to the active submarine volcano Macdonald $\left(160^{\circ} \mathrm{W}, 1^{\circ} \mathrm{S}\right)$ in a band more than $2200 \mathrm{~km}$ long and $240 \mathrm{~km}$ wide (Fig. 6). The chains are composed of several dozens of seamounts, 11 islands and 2 atolls. Although oriented roughly in the direction of present Pacific plate motion $\left(\mathrm{N}_{11} 5^{\circ}\right)$, the spatial and temporal pattern of both the aerial and submarine volcanoes is rather complex. The age of the oceanic crust along the chain ranges from about 39 to $84 \mathrm{Ma}$ (Mayes et al., 1990).

The particular geometry and morphology of the chains suggested two distinct but parallel alignments. McNutt et al. (1997) determined the existence of two additional chains of volcanoes (Taukina and Ngatemato) near the active Macdonald seamount at the southeast end of the chain, 20-34 Ma older than the Macdonald volcanism. Both recent and old ages (Turner \& Jarrard, 1982; Barsczus et al., 1994) recorded on Aitutaki and Rurutu islands from 

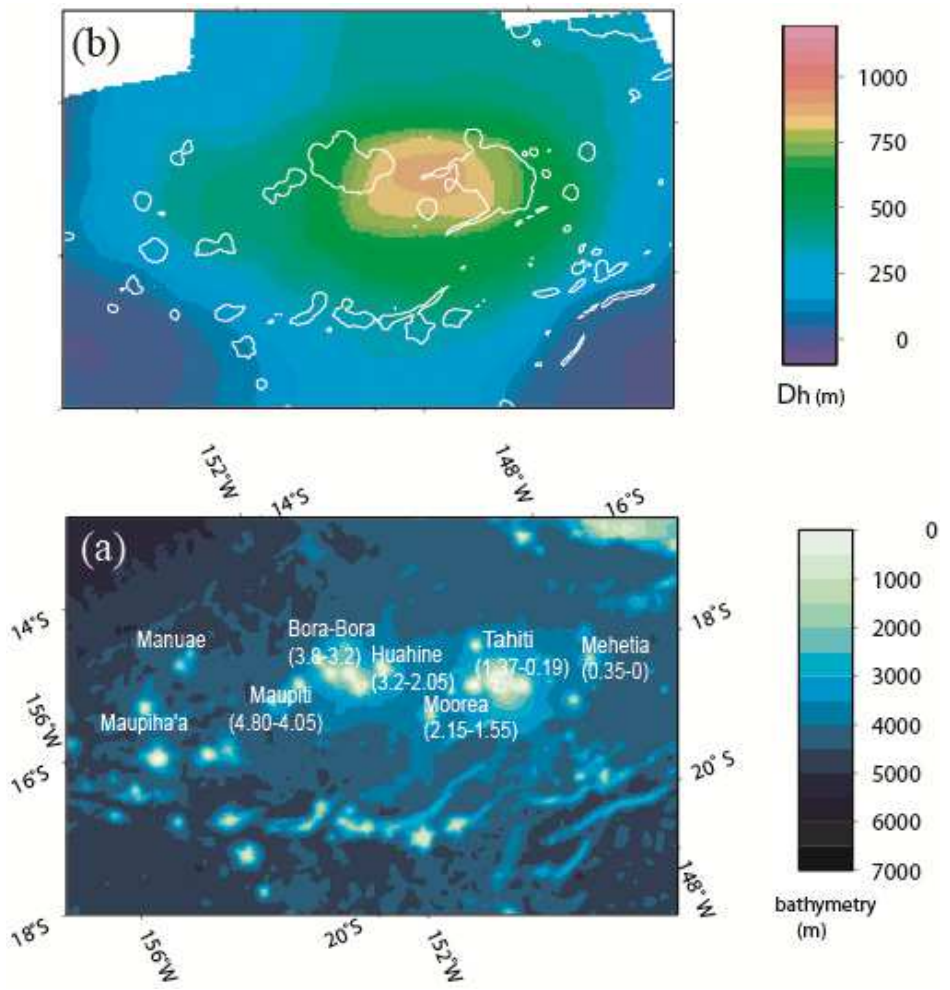

Fig. 5. Society volcanic chain. (a) Bathymetry. The volcanism ages are in Ma. (b) Hot spot swell. Gray line is the $3000 \mathrm{~m}$ isobath. The maps are projected along the direction of the present Pacific plate motion $\left(\mathrm{N} 115^{\circ}\right)$. Figure extracted from Adam et al. (2005)

basaltic samples require the existence of two other hot spots (Rarotonga and Rurutu). Bonneville et al. (2002) attribute the most recent volcanic stage of Rurutu to the Arago Seamount, a very shallow seamount located $120 \mathrm{~km}$ east-southward of Rurutu and sampled during the ZEPOLYF2 cruise. Up to 6 distinct hot spot tracks have been identified so far (Bonneville et al., 2006): from northwest to southeast, Rarotonga, "old" and "young" Rurutu, Macdonald, Taukina and Ngatemato of which three are probably still active: Rarotonga and Macdonald (which are named after the emplacement of the active volcanism) and young Rurutu, now active at the Arago Seamount volcano.

These three active tracks are characterized by coherent age progression and distinct geochemical signatures (Bonneville et al., 2006). Concerning Rarotonga, neither the observed age (1 Ma), nor isotopic analysis allows us to connect it with the above mentioned tracks. It seems to be an isolated hot spot. The same observations can be made for Aitutaki, an atoll situated less than $250 \mathrm{~km}$ north of Rarotonga and dated at 1.2 Ma (Turner \& Jarrard, 1982). The young and old Rurutu tracks overlap each other. Sometimes this occurs on the same volcano, as in Rurutu and Arago. These two tracks occur in the same area as an older phase of volcanism which created the Lotus guyot (54.8 Ma) and the ZEP2-1 seamount (55.8 Ma). To the south, the volcanism which is now active at the Macdonald, and which is responsible for the more recent stage at Marotiri (4 Ma) and ZEP2-19 (8.9 Ma) and for the creation of 
Rapa (5.1 Ma) and Mangaia (20 Ma), also overlaps an older stage which built Ra (29 Ma), Marotiri (32 Ma), ZEP2-19 (20-33 Ma) and the Neilson Bank (40 Ma). The existence of several stages of loading on the same volcanic edifice seems to be the rule rather than the exception in this region.
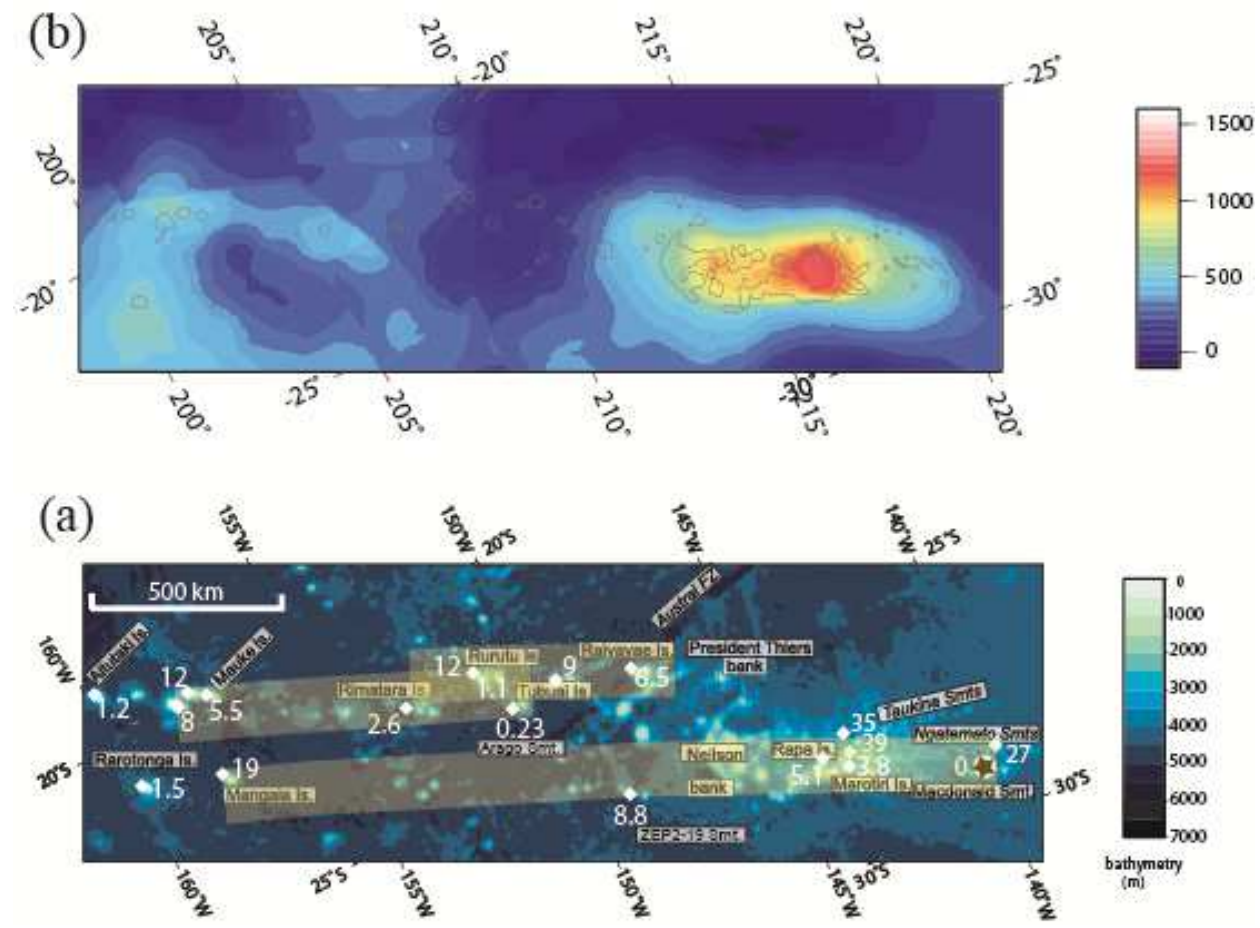

Fig. 6. Cook-Austral volcanic chain. (a) Bathymetry projected along the direction of the present Pacific plate motion $\left(\mathrm{N} 115^{\circ}\right)$. The light green ribbons represent the "old Rurutu", "young Rurutu," and Macdonald hot spot tracks as proposed by Bonneville et al. (2002). Note that volcanoes are often not located exactly on the middle of a track, which could indicate the importance of lithospheric control rather than a change in the location of the magmatic source. The volcanism ages are in Ma. (b) Hot spot swell. Gray line is the $3000 \mathrm{~m}$ isobath. Figure extracted from Adam et al. (2005)

Two positive depth anomalies are observed - one centered on Rarotonga Island and the other one linked to the southwestern branch with Macdonald seamount -, whereas the active Arago seamount is associated with a bathymetric low (Adam et al., 2010). The swell associated with Rarotonga has a circular shape and its maximal amplitude reaches $600 \mathrm{~m}$. The Macdonald swell has an irregular shape: a part of the swell stretches along the axis connecting Macdonald and Rapa; another part is shifted northwest and is not correlated with any recent volcanic structure. The spatial length scale of the swell is about $1250 \mathrm{~km}$. The maximal amplitude reaches $1220 \mathrm{~m}$ and is located $375 \mathrm{~km}$ from the active volcanism (Macdonald), almost twice the distance observed for the Society. 


\subsubsection{Marquesas}

The Marquesas chain seems to be a classical hot spot, with a regular age progression (Duncan \& McDougall, 1974; Diraison, 1991; Brousse et al., 1990) from a seamount southeast of Fatu Iva, which is only a few hundred thousand years old (Desonie et al., 1993), to the Eiao atoll, situated northwest of the chain, displaying an 5.3 Ma age. The direction of this volcanic chain varies according to the authors: McNutt et al. (1989) report a $\mathrm{N} 140-146^{\circ} \mathrm{E}$ direction, whereas Brousse et al. (1990) prefer a $N 160^{\circ}-170^{\circ} \mathrm{E}$ direction. In all cases, this direction differs from those of the Pacific plate motion.

The analysis of seismic velocities points out a crustal thickening of several kilometers (Wolfe et al., 1994; Caress and Chayes, 1995). McNutt and Bonneville (2000) show that the swell associated with this alignment is mostly due to underplating. The swell spreads along the chain axis. Its maximal amplitude $(640 \mathrm{~m})$ is reached on the main axis between Nuku Hiva and Hiva Oa, $275 \mathrm{~km}$ away from the most recent volcanism. It has an irregular shape since its width is almost constant all along the volcanic alignment. When the swell is due to a classical plume-lithosphere interaction, it is more important near the youngest part of the chain. For the Marquesas, this difference confirms the hypothesis of underplating at its origin.

\subsubsection{Tuamotu}

Situated between the Marquesas and Austral Fracture Zones, the Tuamotu volcanic chain has the characteristics of both island chains and oceanic plateaus. The sixty atolls composing the Tuamotu fall under two parallel alignments orientated $\mathrm{N} 115^{\circ} \mathrm{E}$, thus suggesting a hot spot origin (Morgan, 1972; Okal \& Cazenave, 1985). They are superimposed on a large plateau capped with sediments, limestone and basalt layers. The origin of the plateau still remains controversial. Ito et al. (1995) propose a scenario according to which the northern segment of the Pacific-Farallon spreading center propagates southward in an inner pseudofault and a failed rift, and northward in an outer pseudofault. The southern discontinuities would enclose a block of lithosphere transferred from the Farallon plate to the Pacific plate. This zone of discontinuity focuses volcanism along the Tuamotu Plateau, channels the magma uplift and is then responsible for the plateau shape and morphology.

\subsection{The south Pacific superswell}

The term "superswell" was first used by McNutt \& Fischer (1987) to describe a broad area of the Pacific corresponding roughly to French Polynesia (Fig. 3). This region is characterized by numerous geophysical and geochemical anomalies. There is, as previously discussed, a high concentration of volcanism; the seafloor is anomalously shallow considering its age; there is dip in the geoid; the mantle beneath the superswell is characterized by slow seismic velocities.

\subsubsection{Depth anomaly}

The term 'superswell' itself comes from the fact that the seafloor in French Polynesia is unusually shallow compared to other seafloors of the same age. This area subsides less rapidly away from the East Pacific Rise than any thermal subsidence model of the oceanic lithosphere predicts. Mammerickx \& Herron (1980) and Cochran (1986) use the GEBCO bathymetry chart to point out a 15 million $\mathrm{km}^{2}$ elevated area in the South Pacific, to the west of Easter Island. Using SYNBAPS bathymetry, Van Wykhouse (1973) and McNutt \& Fischer (1987) find a broad area of the Pacific where the seafloor is 250 to $750 \mathrm{~m}$ too shallow and 
name it the South Pacific Superswell. This depth anomaly is challenged by Levitt \& Sandwell (1996). They propose that the Superswell could be an artifact of the poor sampling and gridding of ETOPO5, which in oceanic regions corresponds to the SYNBAPS database. Subsequent studies using original ship depth soundings (McNutt et al., 1996; Sichoix et al., 1998) confirm that the seafloor is indeed $1 \mathrm{~km}$ shallower.

The precise description of the location and extent of the superswell remained approximate for a while. One talked indeed about "a region in the South Pacific, to the west of Easter Island" (Mammerickx \& Herron, 1980) or about "a broad area of French Polynesia" (McNutt, 1998). The design of filtering methods, especially adapted for bathymetry (Hillier\& Watts, 2004; Adam et al., 2005) allow a precise quantification of the seafloor uplift in this area. In Fig. 7 we show the depth anomaly found through the MiFil method (Adam et al., 2005, Adam \& Bonneville 2005). It extends between latitudes $10^{\circ} \mathrm{N}$ and $30^{\circ} \mathrm{S}$ and longitudes $130^{\circ} \mathrm{W}$ and $160^{\circ} \mathrm{W}$ and has a maximal amplitude of $680 \mathrm{~m}$ on a seafloor displaying ages between 30 and $115 \mathrm{Ma}$. It is obviously not a simple swell as one thought, but a hemispheric shaped feature, composed of two branches. The southern branch corresponds to the location of French Polynesia. The northern branch, described by Adam \& Bonneville (2005), is not clearly correlated with volcanic features. The only volcanic chain over this area is the Line Islands, which is a fossil alignment displaying ages between 35.5 and 93.4 Ma (Schlanger et al., 1984).

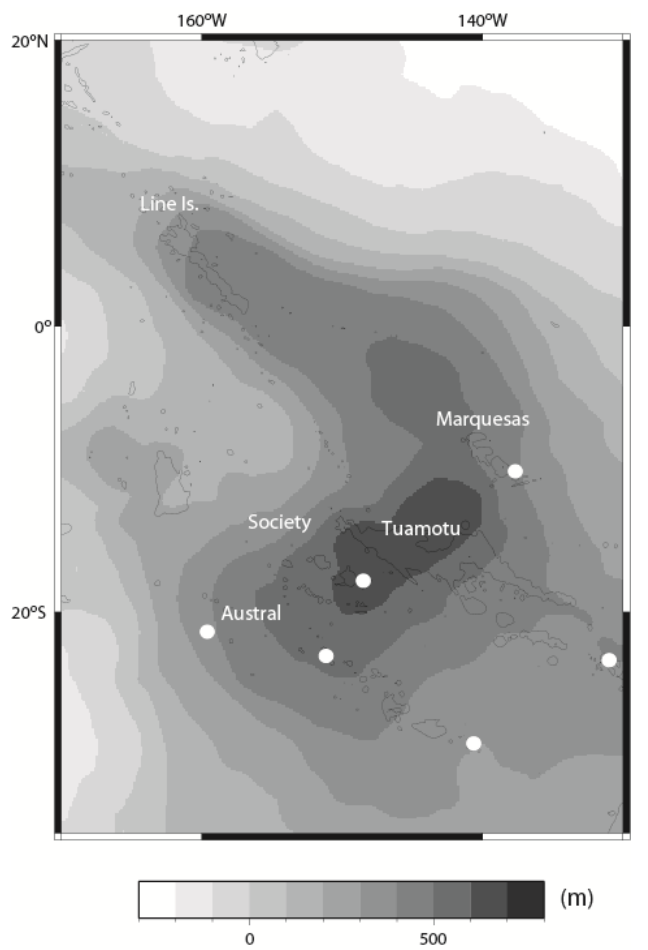

Fig. 7. Depth anomaly associated with the South Pacific Superswell, from Adam \& Bonneville (2005) , computed through the MiFil method (Adam et al., 2005). The white disks represent the emplacement of recent volcanism. 


\subsubsection{Geoid anomaly}

The Superswell area, is also associated with a geoid anomaly. The geoid is an equipotential surface which corresponds to the mean surface of oceans. Departures from this reference bring information on the mass repartition at the interior of the Earth. The correlation between the depth anonaly associated with the Superswell and the geoid is still debated since it is not very clear which long wavelength gravitational field best represents the Superswell. Hager (1984) and Watts et al. (1985), report a geoid high over the Superswell (for spherical harmonic degree and order, of $n=2-10$ and $n>10$ respectively), while McNutt \& Judge(1990), McNutt (1998) and Adam \& Bonneville (2005) suggest this area is correlated with a geoid low ( $\mathrm{n}>4,7<\mathrm{n}<12, \mathrm{n}=6$ respectively).

The influence of choice of the considered degrees and orders illustrated in Fig. 8. This parameter is rather important since it helps constraining the phenomena at the origin of the observed anomalies. The association of swells with a geoid high may be explained by isostatic compensation (Crough,1978, 1983) where the rise of the seafloor is supported by a density deficiency within the lithosphere. A geoid low however, requires dynamic support. The only model which can explain altogether the observed anomalies is a convective mantle where the low-velocity zone is located immediately below the lithosphere (McNutt, 1998).
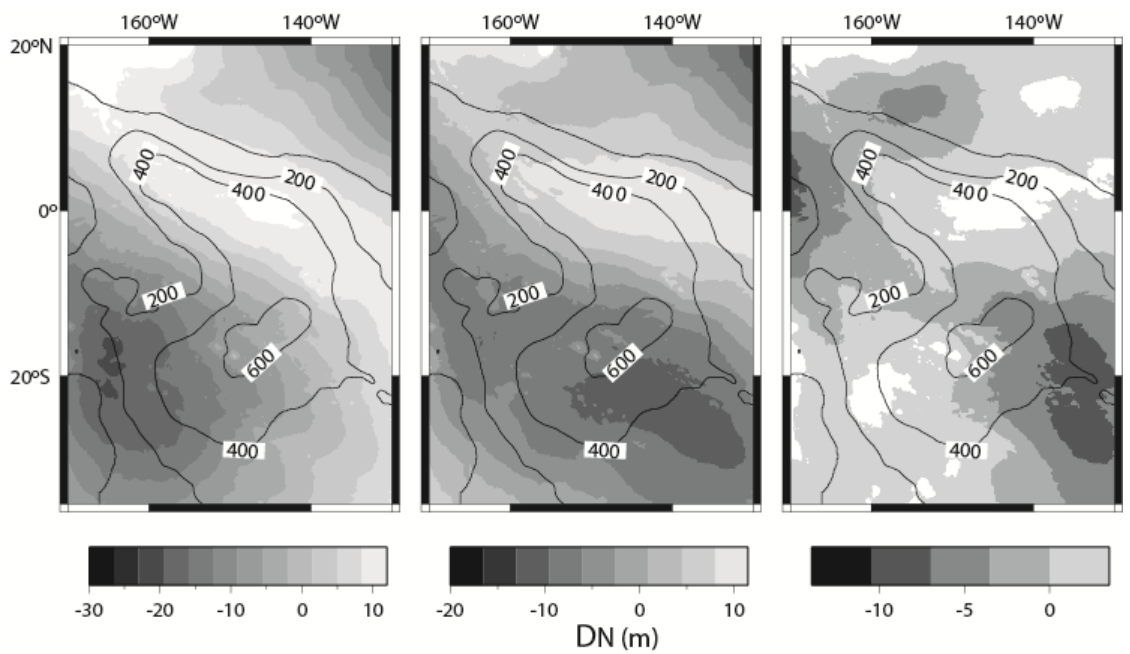

Fig. 8. Geoid anomaly over the superswell: (a) $\lambda>8000 \mathrm{~km}$, (b) $\lambda>6700 \mathrm{~km}$, and (c) $\lambda>5700$ $\mathrm{km}$. Lines show isovalues of the depth anomaly. Figure extracted from Adam \& Bonneville (2005).

The phenomena at the origin of depth and geoid anomalies are constrained by dynamic models, which try to reproduce the convection occurring in the mantle. Some of them use as an input tomography models, which will be discussed in the following.

\subsubsection{Anomalous mantle}

In order to 'look' at the deep mantle, seismic tomography is the most appropriate tool. Seismic tomography is a technique to image a heterogeneous structure of the Earth's interior using vast amount of seismic data, of which principle is same as that of a medical CT scan. 
Studies generally report that the mantle beneath the superswell is characterized by slow seismic velocities (McNutt \& Judge, 1990; Su et al., 1992; Montagner, 2002), but the mantle structure remained poorly resolved for a long time, due to the sparse coverage by seismic stations. This resulted in blurred and even inconsistent images among different studies: some studies have described a whole mantle-scale broad plume (Zhao, 2004), others have proposed a continuous plume conduit generated from a broad plume near the core-mantle boundary (Ritsema \& van Heijst, 2000; Montelli et al., 2006; Takeuchi, 2007, 2009), and still others have suggested plumes that do not continue throughout the mantle (Mégnin \& Romanowicz, 2000).

The recent deployment of two new networks of broad band seismic stations, emplaced on the seafloor (9 BBOBS stations, (Suetsugu et al., 2005)) and on the islands (10 PLUME stations (Barruol et al., 2002)) has lately rectified this. The emplacement of these stations is represented in Fig. 11. From the data obtained through these new stations, several models have been developed. The tomography model provided by Isse et al., (2006) is based on Rayleigh waves inversion and provides the most accurate view of the shallowest part of the mantle (depths $<240 \mathrm{~km}$ ). In its first version, it did however not include the PLUME data. These latter are included by Suetsugu et al. (2009), who determine the mantle structure of the upper mantle down to $400 \mathrm{~km}$ by inverting the dispersion for the $S$ wave velocity. The authors also update the map of the MTZ thickness by applying the receiver function analysis to the PLUME data. To analyze the lower mantle structure, Suetsugu et al. (2009) design a P wave travel time tomography. Tanaka et al.(2009a, 2009b) also obtain a P and S wave traveltime tomography and a global $\mathrm{P}$ wave traveltime tomography (2009a) from the BBOBS and PLUME data. The main results are summarized in the composite Fig. 9.

There is no uniform anomaly throughout the upper mantle, and the average $S$ velocity profile beneath the South Pacific superswell is close to that of other oceanic regions. On shorter scales, there are slow (of about 2-3\%), localized anomalies, which could represent narrow plumes in the upper mantle. They appear to be deep-rooted beneath Society, Macdonald and Pitcairn, and superficial beneath the Marquesas $(<150 \mathrm{~km})$. These anomalies are not necessarily vertical. The one in the vicinity of the Macdonald hot spot, is located 200$300 \mathrm{~km}$ northwest of the hot spot.

The mantle transition zone (MTZ) is defined as a layer bounded by two seismic discontinuities: the $410 \mathrm{~km}$ and $660 \mathrm{~km}$ discontinuities, which represent mineral phase transition, and provide indirect information regarding the temperature. The average MTZ thickness beneath the South Pacific is close to the global average, and values beneath most of the stations are nearly normal, with some notable exceptions. The MTZ is indeed thinned near the Society, the Macdonald and the Pitcairn hot spots, suggesting that hot plumes may be ascending from the lower mantle.

Low velocity anomalies are found throughout the lower mantle, while the lateral dimension of the anomalies changes drastically at a depth of $1000 \mathrm{~km}$ (Fig. 9). Below $1000 \mathrm{~km}$, slow anomalies of $1 \%$ are as large as $3000 \mathrm{~km}^{*} 3000 \mathrm{~km}$. They seem continuous down to the coremantle boundary. On the other hand, above $1000 \mathrm{~km}$, the slow anomalies split into narrower and more localized anomalies, a few hundred kilometers in diameter.

These new images suggest that the narrow slow anomalies observed in the first $400 \mathrm{~km}$ of the upper mantle may be connected to the top surface of the superplume. These narrow anomalies are smaller than the spatial resolution of the lower mantle model. The distribution of the MTZ thickness, however, supports the presence of these narrow 
anomalies. In the case of Society and Macdonald, these anomalies also coincide with the slower anomalies in the upper mantle, which suggests that they represent continuous plumes that ascend from the top surface of the superplume. The Marquesas hot spot seem to be restricted to the upper mantle, as well as Pitcairn, which is characterized by slow upper mantle and a thin MTZ, but with no slow anomalies at the top of the lower mantle.
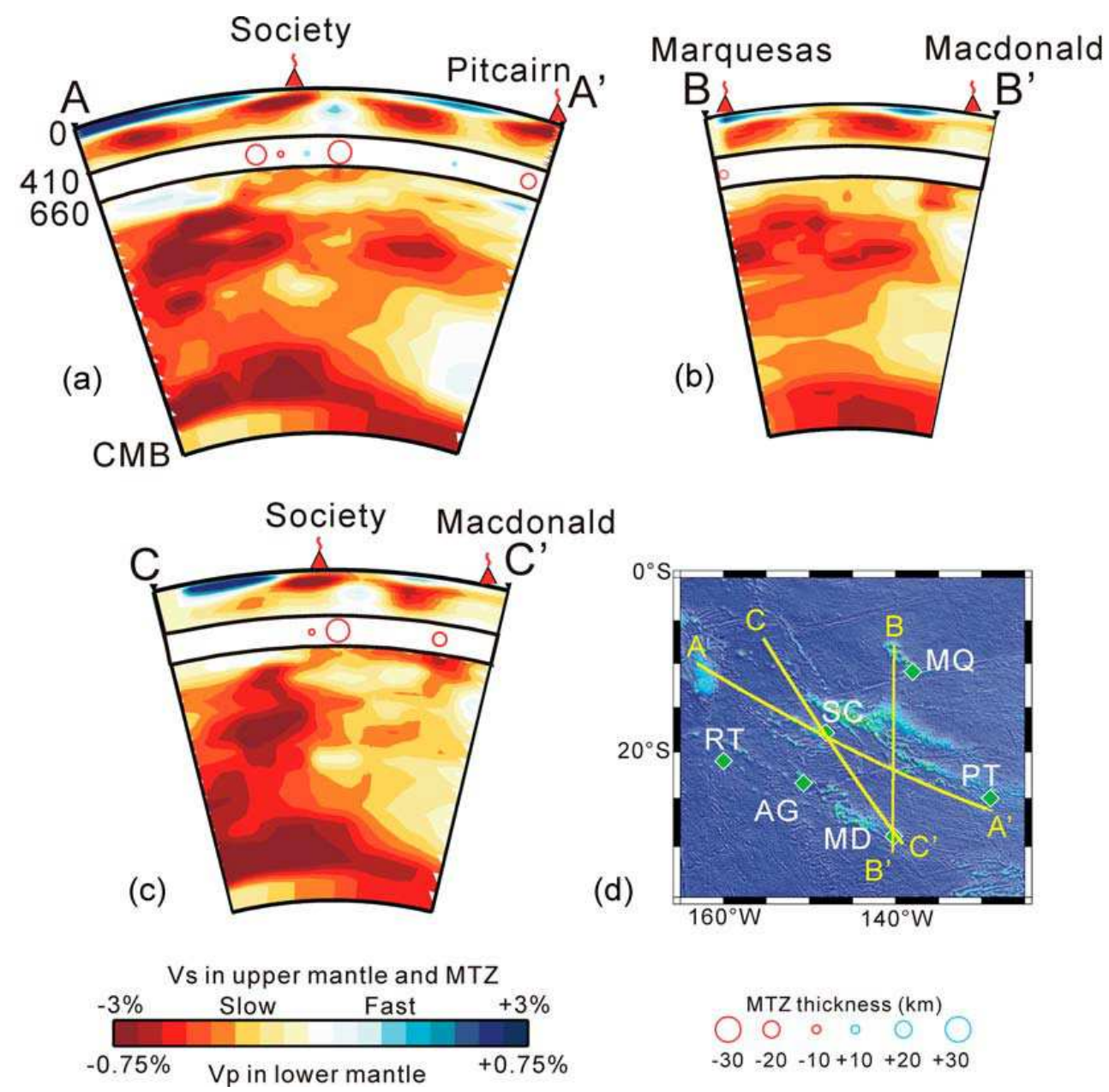

(d)
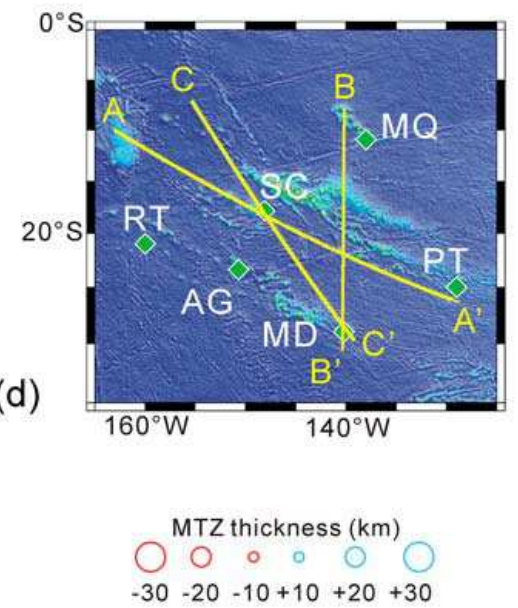

Fig. 9. Composite tomography from Suetsugu et al. 2009 (a-c) Cross sections of seismic structure in the entire mantle. $S$ wave velocities are shown for the upper mantle $(0-410 \mathrm{~km})$. $P$ wave velocities are shown for the lower mantle $(660-2900 \mathrm{~km})$. Velocity scales are $\pm 3 \%$ in the upper mantle and $\pm 0.75 \%$ in the lower mantle. (d) Positions of the profiles. Circles plotted in the MTZ (410-660 km) are the locations of the MTZ thickness estimated near the profiles within $2.5^{\circ}$, where red and blue represent thicker and thinner than the global average, respectively, and the size is proportional to the deviation from the average. Green diamonds in are active hot spots. 


\section{Models, interpretation}

The phenomenon connecting the surface observations (volcanic chains, swells, the geophysical anomalies associated with the South Pacific Superswell) and the mantle structure are still debated. The dynamics of mantle plumes and Superplumes, and the origin of their associated swells, remain indeed some of the most controversial topics in geodynamics. In the following, we will provide a detailed description of Adam et al. (2010) study, which focuses on the dynamics of the shallowest part of the mantle under the French Polynesia region.

\subsection{Dynamics of the French Polynesia plumes: Results of numerical simulations based on a highly resolved tomography model}

Adam et al. (2010) use a new regional seismic tomography model obtained through the inversion of Rayleigh waves (see section 3.3.3), which high resolution allows obtaining information at the scale of plumes. They construct a numerical model of the mantle flow beneath the French Polynesia region. We will describe at first the numerical model, then compare the outputs of the numerical modeling to the surface observations.

\subsubsection{Model}

\section{Convection model}

Adam's et al. (2010) study is a local study, where the computation domain extends between latitudes 0 and $32^{\circ} \mathrm{S}$, longitudes 174 and $232^{\circ} \mathrm{E}$, and depths $0-240 \mathrm{~km}$. Following the work of Yoshida (2008), the authors used the finite volume method for the discretization of the basic equations.

The non-dimensionalized expressions of the mass and momentum equation are:

$$
\begin{gathered}
\nabla \cdot v=0 \\
-\nabla p+\nabla \cdot\left\{\eta\left(\nabla v+\nabla v^{t r}\right)\right\}+R_{a i} \delta \rho e_{r}
\end{gathered}
$$

where $v$ is the velocity vector, $p$ the dynamic pressure, $\eta$ the viscosity, $\delta \rho$ the density anomaly, $R a_{i}$ the instantaneous Rayleigh number, and $\boldsymbol{e}_{r}$, the unit vector in the radial direction. The superscript $t r$ indicates the tensor transpose. The impermeable and shear stress-free conditions are adopted on the top ( $0 \mathrm{~km}$ depth) and bottom (240 km depth) surface boundaries. The flows across lateral boundaries are taken to be symmetric.

The resulting normal stress acting on the top surface boundary $\left(\sigma_{\mathrm{rr}}\right)$ is

$$
\sigma_{r r}=-p+2 \eta \frac{\partial v_{r}}{\partial r}
$$

where $v_{r}$ is the radial velocity. The dynamic topography $\delta h$ is obtained from the normal stress through the equation

$$
\delta h=\frac{\sigma_{r r}-\left\langle\sigma_{r r}\right\rangle}{\Delta \rho g}
$$

where $\left\langle\sigma_{r r}\right\rangle$ is the averaged $\sigma_{\mathrm{rr}}$ over the top surface boundary, $\delta \rho$ the density contrast between the mantle and sea water densities and $g$, the gravity acceleration. 


\section{Model parameters}

Ratio of density anomaly to seismic velocity anomaly, $R_{\rho / v s}$

The density to velocity heterogeneity ratio $R_{\rho / v s}$ used to convert the seismic waves velocity anomalies into density anomalies, is a primordial parameter of the model since it allows to make geodynamical inferences from a tomography model. In the range of viscosity profiles tested by Adam et al. (2010), the density to velocity heterogeneity ratio, $R_{\rho / v s}$, allowing the best fit of the observations is situated between 0.14 and 0.24 . These values are quite close to the value inferred from mineral physics $\left(R_{\rho / v s}=0.2\right.$, Karato, (2008)). The $R_{\rho / v s}$ is slightly bigger than the former estimation found through similar geodynamic models $\left(R_{\rho / v s}=0.1\right.$ to 0.15 for Forte and Mitrovica (2001), $R_{\rho / v s}=-0.01$ to 0.07 according to Simmons (2007)), certainly because these previous studies never focused on such shallow depths. The results presented hereafter use a density to velocity heterogeneity ratio $R_{\rho / v s}$ of 0.17 .

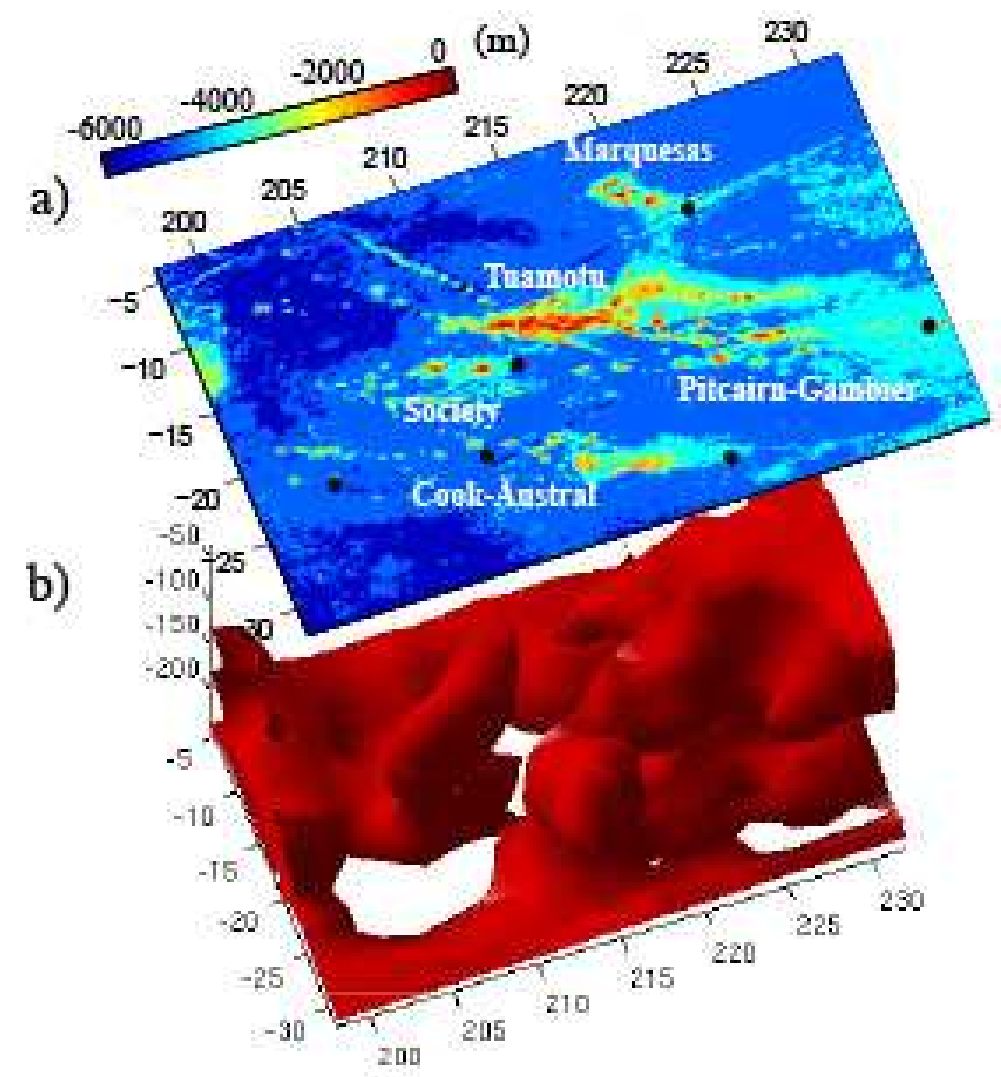

Fig. 10. French Polynesia region - from Adam et al. (2010). a) Bathymetry and names of the hotspot chains. The black disks represent the young volcanoes. b) View of the mantle density anomalies deduced from the tomography model. The red iso-surface represents the $30 \mathrm{kgm}^{-3}$ density anomaly. 


\section{Viscosity profile}

Adam et al. (2010) also tested the effects of vertical variation of the viscosity (see their Supplementary Online Material). The introduced viscosity profile describes a highly viscous lithosphere overlying a low-viscosity asthenosphere. Note that while the absolute velocity of mantle flow is affected by the choice of the relative viscosity of each layer, the dynamic topography does not depend on its absolute viscosity. We present here the results obtained with viscosity of $10^{23}$ Pas between depths 0 and $30 \mathrm{~km}$ and viscosity of $10^{20}$ Pas between depths 30 and $240 \mathrm{~km}$.

\section{Influence of deeper heterogeneities}

In the present study Adam et al. (2010) limited the depth range from 0 to $240 \mathrm{~km}$, which covers the lithosphere and asthenosphere. To examine the effects of the density heterogeneities situated deeper than $240 \mathrm{~km}$, the authors also constructed a composite tomography model in which they impose in the upper part $(0-240 \mathrm{~km}$ depths $)$ the local Rayleigh wave tomography model (Isse et al., 2006) and in the lower part $(260-660 \mathrm{~km})$ the S20RTS model (Ritsema \& van Heist, 2000). They then compute the whole upper mantle convection $(0-660 \mathrm{~km})$ by varying the viscosity below the asthenosphere. The viscosity profile above $240 \mathrm{~km}$ remains the same as previously described (highly viscous lithosphere overlying a low-viscosity asthenosphere). When the viscosity below the asthenosphere is greater than in the asthenosphere, say, $\eta=10^{21}-10^{22}$ Pas between depths 240 and $660 \mathrm{~km}$, the convection is very similar to the convection obtained in the present study (depths $0-240 \mathrm{~km}$ ), because the viscosity increase at the base of the asthenosphere $(240 \mathrm{~km}$ depth) reduces the flow velocity created in the lower part of the mantle. The increase of viscosity below the asthenosphere is a reasonable assumption, which has been supported by many previous studies (Dziewonski \& Anderson, 1981). They therefore conclude that the convection computed from the upper $240 \mathrm{~km}$ of the mantle is representing well the actual convection in this depth range.

\subsubsection{Hotspot swells and dynamic topography}

The dynamic topography computed by Adam et al. (2010) is presented in Fig. 11. The authors notice a good overall correlation between the observed (Fig. $11 \mathrm{~b}$ ) and the modelled swells (Fig. $11 \mathrm{c}$ ), in spite the fact that they have been obtained from totally independent data (bathymetry and seismic tomograms respectively). Previous studies (Crough, 1978; Sleep, 1990) show that midplate chains are generally associated with bathymetric highs. The emplacement, wavelength and amplitude of the French Polynesia swells are well recovered by Adam et al. (2010) model, indicating the authors reproduce well the actual mantle flow. The swell over the Society chain, the only classical hotspot chain in the study area has indeed the same characteristics that the dynamic topography. The swell over PitcairnGambier and the circular swell associated with Rarotonga, an isolated active volcano, are also well retrieved.

As discussed in section 3.1.2, the situation is quite puzzling for the Macdonald chain, since previous studies demonstrate that most of the volcanism there may be produced by nonhotspot processes (McNutt et al., 1997; Jordahl 2004). The fact that the swells are well modelled by the dynamic topography, demonstrates that the buoyant ascent of the plume plays a major role. In section 3.1, we have seen that the Marquesas and the Tuamotu swells probably have shallow origins, respectively crustal underplating (McNutt \& Bonneville, 2000) and a large plateau capped with sediments, limestone and basalt layers (Ito et al., 

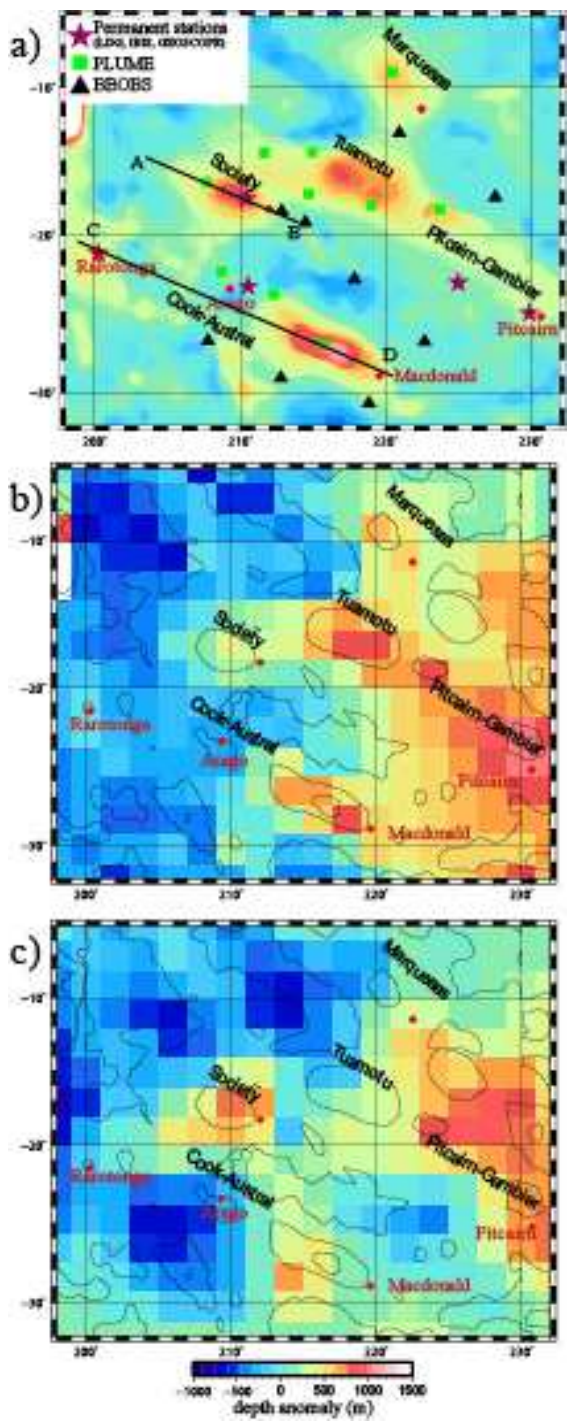

Fig. 11. French Polynesia swells- from Adam et al. (2010): a) The colour map represents the observed swells, determined by the same method that Adam et al. (2005). The red disks represent the location of active volcanism. The seismic station emplacement is shown by the magenta crosses (permanent stations), the green squares (PLUME stations) and the red circles (BBOBS). The AB and CD profiles are used to make depth cross sections (see Fig. 12 and discussion in the text). b) Observed swells with age correction and $2^{\circ *} 2^{\circ}$ sampling. The black lines represent the isocontours of the original swells displayed in panel a. c) Dynamic topography obtained through a computation using $R_{\rho / v s}=0.17$ and a viscosity profile which describes a highly viscous lithosphere $\left(10^{23}\right.$ Pas between depths 0 and $\left.30 \mathrm{~km}\right)$ overlying a low-viscosity asthenosphere (1020 Pas between depths 30 and $240 \mathrm{~km})$. 
1995). It is then not surprising that these chains are not associated with any important dynamic topography. The new modelling however, points out a distinct area of localized upwelling, east of the Tuamotu plateau, which may be the first evidence that the presentday mantle dynamics contributes to the observed depth anomaly.

The model also recovers the observed bathymetric lows such as the one associated with the active Arago volcano, there again with the correct emplacement, wavelength and amplitude. This pattern is actually surprising since active volcanism is generally associated with bathymetric high, created by the buoyant uplift of a plume. Latter, we will check in more details what is happening, by looking at the convection occurring beneath this region.

The convection modelled by Adam et al. (2010) is represented in Fig. 12. The pattern is quite complex. Volcanism emplacement is not due to a simple vertical ascent of a plume, but rather to a complex interaction between upwelling and downwelling flows. The only case in the study area which corresponds to the definition originally proposed (Morgan, 1968), is the Society. On the depth cross section along the AB profile (Fig. 12 a), we can see indeed that the buoyant source (negative density anomaly) located under this chain creates a vertical upwelling reaching the lithosphere directly beneath the active volcanism. For all the other chains, the convection pattern is more complex. It is not merely created by deep buoyant sources but mainly controlled by the surrounding mantle flows. Therefore, the inferred mantle convection involves lateral flows, tilted conduits and the buoyant source is generally far from the active volcanism. However, Adam et al. (2010) find that the emplacement of each active volcano can be explained by the modelled flows.

The Cook-Austral chain has often been taken as an example to argue against the plume theory (McNutt at al., 1997; Jordahl 2004), since volcanic stages overlap on this chain (Bonneville at al., 2006) and the latest volcanic emplacement is apparently controlled by the stresses left in the lithosphere by previous loadings (McNutt at al., 1997). It is then interesting to check the convection under this chain. On the depth cross section along the CD profile (Fig. 12b), a large low density body, deeper than $50 \mathrm{~km}$, creates an upwelling beneath the observed swell maximum, but far from the active volcanism occurring at Macdonald. At the base of the lithosphere the flow becomes horizontal and streams towards the Macdonald. This explains the volcanism emplacement. Even if this latter may be facilitated by structural discontinuities of the lithosphere, as previously suggested (McNutt at al., 1997; Jordahl 2004), the present result demonstrates that the buoyant ascent of the plume plays a major role in the volcanism loading.

The bathymetric low observed near the Arago active volcano is also puzzling. We can see that the mantle under this volcano is indeed characterized by densities slightly higher than the surrounding mantle (Fig. 12 b). This accounts for the observed and modelled bathymetric lows but does explain the volcanism emplacement. One would expect a hot buoyant mantle upwelling. How can active volcanism be associated with cooler mantle? Maybe through the downwelling current this configuration creates. This downwelling current may produce lateral tensile stresses and then cracks near the base of the lithosphere. The magma will simply follow this lithospheric discontinuities and erupt as pressure decrease along the way.

The low density buoyant source associated with the upwelling creating Rarotonga, is situated far from this volcano, at depths greater than $140 \mathrm{~km}$ and more than $500 \mathrm{~km}$ west of the island. The mantle in the immediate vicinity is indeed slightly cooler. The upwelling reaches the lithosphere through a tilted conduit, and occurs surprisingly through a mantle which is not especially hotter than the surroundings. The buoyancy created by the deep source $(140-240 \mathrm{~km}$ depths), should be strong enough to counterbalance the adjacent mantle buoyancy. 

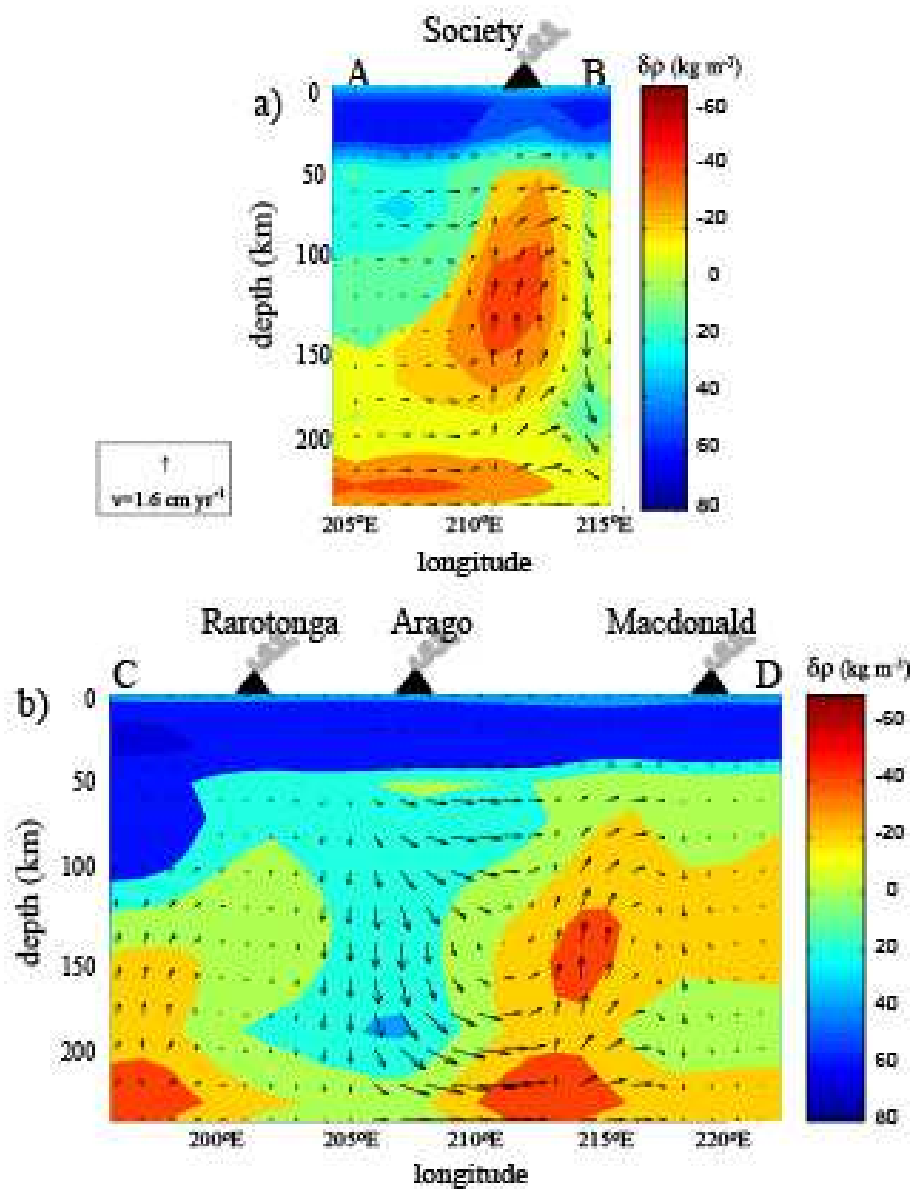

Fig. 12. Depth cross section along the $\mathrm{AB}(\mathrm{a})$ and $\mathrm{CD}(\mathrm{b})$ profiles displayed in Figure 11 from Adam et al. (2010). The colour map represents the density anomalies and the arrows the convection driven by them. The schematic volcanoes represent the active volcanism emplacement.

\subsubsection{Buoyancy fluxes}

Quantitatively, the measure of the plume strength is given by the buoyancy flux, which measures the flux of material from the mantle. The buoyancy flux can be computed through two independent ways, one based on swell morphology ( $\left.B_{\text {swells }}\right)$, and the other on the mantle flow ( $\left.B_{\text {dyn }}\right)$ (Davies, 1988, Sleep 1990). $B_{\text {swells }}$ has been obtained through the formula

$$
B_{\text {swells }}=W E\left(\rho_{m}-\rho_{w}\right) V_{l}
$$

where $E$ is swell's amplitude, $W$ its lateral extent, $\left(\rho_{m}-\rho_{w}\right)$ the density contrast between the mantle and the seawater and $V_{l}$ the Pacific plate velocity $B_{\text {dyn }}$ is defined at each depth as: 


$$
B_{d y n}=-\int_{s}\left(v_{r} \delta \rho\right) d s
$$

where $v_{r}$ is the radial velocity obtained by the dynamic model and $d \rho$ the input density anomaly. The integration is carried out over the horizontal cross-sectional area of plumes. We assumed that regions with $v_{r}>0\left(v_{r}<0\right)$ are those of upwelling (downwelling) plumes. The values obtained by Adam et al. (2010) are represented in Fig. 13. We can see that the results obtained through the two approaches are very consistent. Indeed, both of the B estimations give the same lineup of the hotspot strength. From the strongest to the weakest

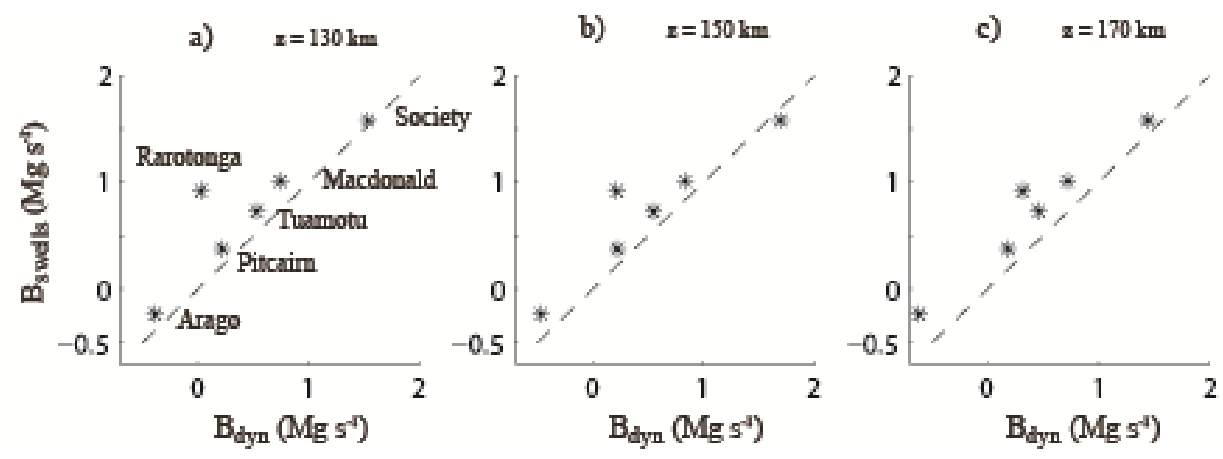

Fig. 13. Buoyancy fluxes from Adam et al. (2010). The values of the buoyancy fluxes obtained from the observed swells ( $\mathrm{B}_{\text {swells }}$ ) are represented as a function of the buoyancy fluxes obtained through the dynamic computation $\left(B_{\text {dyn }}\right)$ for various depths $(130 \mathrm{~km}, 150$ $\mathrm{km}$, and $170 \mathrm{~km}$ ). We represent the values obtained through a computation using $R_{\rho / v s}=0.17$ and a viscosity profile which describes a highly viscous lithosphere $10^{23}$ Pas between depths 0 and $30 \mathrm{~km})$ overlying a low-viscosity asthenosphere (1020 Pas between depths 30 and $240 \mathrm{~km}$ ). The dashed line represent the $B_{\text {dyn }}=B_{\text {swells }}$ curve.

we find the Society, Macdonald, Rarotonga, Tuamotu, Pitcairn and Arago. The Society and Macdonald ones are the only "strong" plumes, with B $>1 \mathrm{Mgs}^{-1}$ (Courtillot et al., 2003). The fact that the buoyancy fluxes values found through the two independent approaches are consistent, implies that the heat transported by mantle plumes can be accurately evaluated from a careful estimation of the swell morphology. This is important for constraining the role that plumes play into the total heat flow on Earth. Adam et al. (2010) find that the total buoyancy flux $\mathrm{B}_{\text {total }}$ of the five hotspots (except Marquesas and Arago) is $4.7 \mathrm{Mgs}^{-1}$. Taking the thermal expansivity $\alpha=2.0 \times 10^{-5} \mathrm{~K}^{-1}$ and the specific heat $c p=1250 \mathrm{Jkg}^{-1} \mathrm{~K}^{-1}$, the total heat flow is estimated as $\mathrm{Q}=B_{\text {total }} C p / \alpha=0.29 \mathrm{TW}$ (Davies, 1999), which accounts for $9 \%$ of the total plume heat flow, 3.4 TW (Sleep, 1990), and for around 1\% of the total heat flow out of the Earth's mantle, 36 TW (Davies, 1999)

\section{Discussion}

French Polynesia is a complex region, characterized by numerous geophysical anomalies. There is indeed a high concentration of volcanism: $14 \%$ of the active volcanism is concentrated in an area covering less than $5 \%$ of the globe. There is a wide range of volcanic features: en echelon ridges, isolated seamounts, and five chains of midplate volcanoes. 
Their characteristics often depart from the classical definition of a hotspot chains: the age progression in the volcanic chains is often short, the orientation of the chains do not systematically correspond to the motion of the oceanic plate, and the lithosphere seems to exert a considerable influence on the location of the volcanism, like in the Cook-Austral Austral Islands, where several periods of linear volcanism are superimposed.

The morphology of the swells associated with these chains is also peculiar and does not correspond to the classical definition of a hotspot swell (Crough, 1978; Sleep, 1990). Adam et al. (2010) show that they are well correlated to the dynamic topography modelled from a regional, highly resolved seismic tomography model, which concerns only the first $240 \mathrm{~km}$ of the upper mantle. This demonstrates that a direct link exists between the surface observations and mantle flows. However, according to the classical definition, plumes should be deep-rooted buoyant mantle upwellings. We have seen that the convection occurring in the shallowest part of the mantle (0-240 km depths) is sufficient to explain the active volcanism and the observed swells, while the roots of some hotspots are probably located at greater depths, as indicated by a recent tomography model (Suetsugu et al., 2009). The buoyancy created by these deeper sources is apparently not required to explain the surface observations.

The snapshot of the mantle provided by the tomography models display a complex pattern. Low velocity anomalies are found throughout the lower mantle, but their dimension changes drastically at a depth of $1000 \mathrm{~km}$. The broad anomaly extending from the CMB, splits indeed into narrower and more localized anomalies a few hundred kilometers in diameter. Narrow anomalies are observed in the upper mantle. The Society and Macdonald ones seem to be connected to the lower mantle, whereas the other are restricted to the upper mantle.

We have shown that the dynamics of the narrow plumes concerns the shallowest part of the mantle (depths 0-240 km). What about the broad deeper anomaly, called superplume? Through the model described in section 4.1.1, the dynamics of this superplume has also been studied (Adam, Yoshida \& Suetsugu, personal communication). The effects of the upper and lower mantle have been tested separately. The tomography models are the S20RTS model (Ritsema \& van Heist, 2000) for the upper mantle and the Obayashi \& Fukao model (2000) for the lower mantle. The preliminary results displayed in Fig. 14 show that the depth anomaly associated with the South Pacific Superswell can only be accounted for when considering the dynamics of the lower mantle. Indeed, the dynamic topography computed from the upper mantle (lef panel Fig. 14) has a faint amplitude and the wavelength is much shorter than the observations. The wavelength and emplacement of the observed depth anomaly is well recovered when modeling the dynamics of the lower mantle (right panel Fig. 14). This points out to the fact that the Superswell is a phenomenon involving mainly the lower mantle.

What is the connection between all these observed features? In a traditional view, hot upwellings in the lower mantle are stuck below the " 660 ' discontinuity'. Suetsugu's et al. (2009) study reveals however that the top of the superplume is located at a depth of $1000 \mathrm{~km}$ and that there are no broad slow anomalies immediately beneath the "660. Moreover, the morphology of the superplume imaged by Suetsugu's et al. (2009) does not correspond to the image of a thermal plume, as defined on the basis of laboratory and numerical experiments, which often show that purely thermal plumes are characterized by a broad head and a narrow tail. This points out to a thermo-chemical origin. The size of the Superswell also indicate such an origin. Models studying the dynamics of boundary layers, 
show that the maximum diameter reached by a plume that has only a thermal origin is in the range of a few hundred kilometers (Bercovici \& Kelly, 1997; Schubert et al., 2004). If other phenomena such as compositional effect are considered, this might stabilize the boundary layer and allow it to thicken toward the superplume dimension.

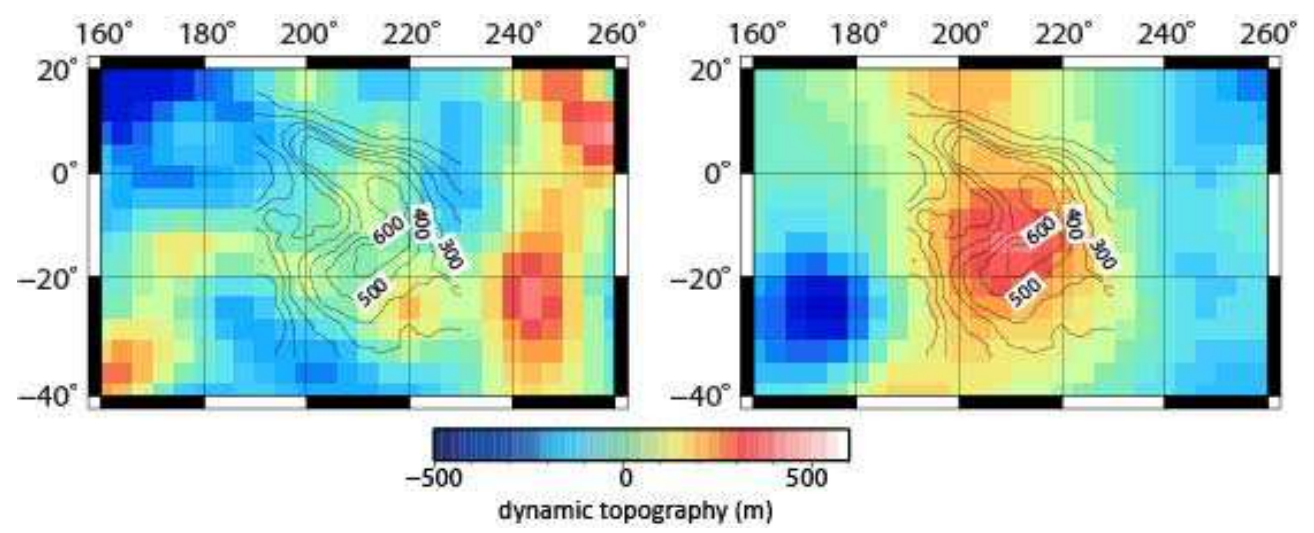

Fig. 14. Dynamics of the South Pacific Superswell. The left and right panels represent the dynamic topography computed for the upper and lower mantle respectively (Adam, Yoshida \& Suetsugu, personal communication). The black isocontours represent the depth anomaly associated to the Superswell (Adam \& Bonneville, 2005).

Courtillot et al. (2003) argue out that two types of upwellings can occur in the lower mantle: the primary plumes and the superplumes. The type of upwelling depend on the local buoyancy ratio (i.e., the ratio of the stabilizing chemical density anomaly to the destabilizing thermal density anomaly). These results are based on analogical experiments where two layers of miscible fluids with different kinematic viscosities, densities and depths, superimposed in a tank heated from below and cooled from above (Davaille, 1999; Le Bars \& Davaille, 2004; Kumagai et al., 2007). For high buoyancy ratio, long-lived thermochemical plumes are produced, whereas for intermediate buoyancy ratios, large thermal domes develop. In this case, the lower (respectively upper) fluid is heated (respectively cooled), becomes lighter (respectively heavier) and rises up (respectively sinks) until the thermal effects are cancelled by the chemical density anomaly. This large domes oscillates vertically. Experimentally, secondary plumes are observed at the top of the rising domes (arrows in Fig. 15), where the ratio of the chemical density anomaly to the thermal density anomaly is higher than in the rest of the mantle.

The morphology obtained through these experiments is very similar to the geometry of the superplume and narrow plumes imaged by Suetsugu et al. (2009). The Society and the Macdonald seem to be still connected with the superplume. The other observed narrow plumes may represent (remnant) secondary plumes that have detached from the superplume. Such a dome structure has also been found through numerical simulations (McNamara \& Zhong, 2004; Farnetani \& Samuel, 2005; Ogawa, 2007). Analogic experiments also shown that secondary plumes are generated sporadically and do not last for a long time (Davaille, 1999; Ogawa, 2007). This may explain the short age progressions of the Polynesian hot spots (Duncan \& MacDougall, 1976; Clouard \& Bonneville, 2005). Moreover, if the emphasized secondary plumes entrain chemically distinct superplume materials, from 
different location and in different proportions, this would explain the enriched mantle signature found in the South Pacific OIB, and the different geochemical signatures that have been observed (Bonneville et al., 2006). If the experimentally observed vertical oscillation of the large dome are actually representative of the superplume behavior, this would also explain the present-day relative quietness of the volcanic activity and deep location of the superplume. Vertical oscillation will indeed induce pulsation in the volcanic activity, which was increased in the Cretaceous, when it created large oceanic plateaus.

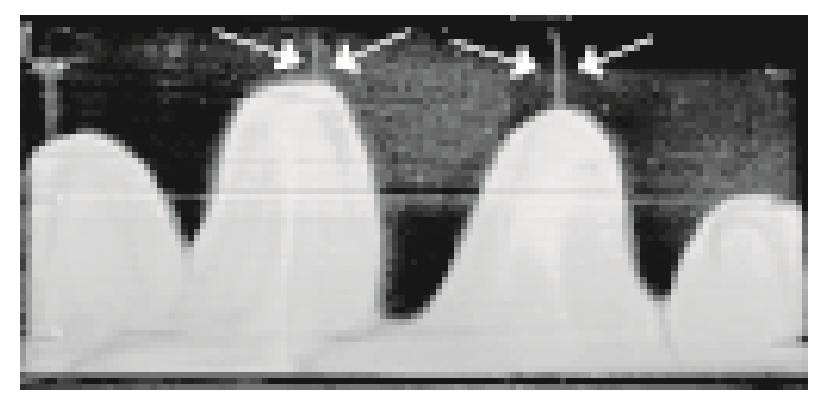

Fig. 15. Convection driven by two layers of miscible fluids submitted to a temperature gradient. For intermediate values of the stabilizing chemical density anomaly to the destabilizing thermal density anomaly, large domes develop and oscillate vertically through the whole layer. Thin plumes rise from the upper surfaces of the domes (white arrows) (Davaille, 1999).

The volcanism pattern and mantle dynamics under the French Polynesia region are quite complex. Magma uplift obviously does not occur through deep vertical conduits as first proposed (Morgan, 1971; 1972), but rather through narrow secondary plume, probably initiating at top of a large oscillating dome, the superplume. The volcanism emplacement is not a passive phenomenon, only due to discontinuities of the lithosphere. Mantle dynamics is required, even if it involves only the shallowest part of the mantle ( $0-240 \mathrm{~km}$ depths). Anderson (2010) uses the results of Adam et al. (2010) on the dynamics of secondary plumes, to argue that hotspots are shallow phenomena, involving only the shallow asthenosphere. Even if the dynamics of this later is sufficient to explain the surface observations, the narrow secondary plumes may have not existed without the superplume, which appears to be related with the lower mantle dynamics.

\section{References}

Adam, C., Vidal V. , \& Bonneville A. (2005). MiFil: a method to characterize hotspot swells with application to the South Central Pacific. Geochem. Geophys. Geosyst., 6, Q01003, doi:10.1029/2004GC000814.

Adam, C. \& Bonneville A. (2005). Extent of the South Pacific Superswell, J. Geophys. Res., 110, B09408, doi:10.1029/2004JB00346.

Adam, C., Yoshida M., Isse T., Suetsugu D., Fukao Y., \& Barruol G. (2010). South Pacific hotspot swells dynamically supported by mantle flows. Geophys. Res. Lett. VOL. 37, L08302, doi:10.1029/2010GL042534.

Allègre C.J. (2002). The evolution of mantle mixing, Philos. Trans. R. Soc. London 360, 1-21. 
Anderson, D. (1975). Chemical plumes in the mantle. Tectonophysics, 86, 1593-1600.

Anderson, D. (1998).The Helium Paradoxes, Proc. Natl. Acad. Sci. USA 95, 4822-4827.

Anderson, D. (2000). The thermal state of the upper mantle: no role for mantle plumes. Geophys. Res. Lett., 27, 1593-1600.

Anderson, D. (2010). Hawaii, Boundary Layers and Ambient Mantle-Geophysical Constraints.. J. of Petrology, doi:10.1093/petrology/egq068

Barruol, G., Bosh, D., Clouard, V., Debayle, E., Doin, M.P., Fontaine, F., Godard, M., Masson, F., Tommasi, A. \& Thoraval C. (2002). PLUME investigates the South Pacific Superswell. Eos, Trans. Am. Geophys. Un., 83, 511-514.

Barsczus, H., Guille, G., Maury, R., Chauvel, C., \& Guillou, H. (1994). Two magmatic sources at Rurutu Island (Austral Islands, French Polynesia) and the Austral Hotline. In Eos trans., 75, 323.

Bercovici, D., \& Kelly, A. (1997). The non-linear initiation of diapirs and plume heads. Phys. Earth Planet. Inter., 101, 119-130.

Bonneville, A., Lesuave, R., Audin, L., Clouard, V., Dosso, L., Gillot, P., Hildenbrandt, A., Janey, P., \& Jordhal, K. (2002). Arago seamount: the missing Hot Spot found in the Austral islands. Geology, 1023-1026.

Bonneville, A., Dosso, L., \& Hildenbrand, A. (2006), Temporal evolution and geochemical variability of the South Pacific superplume activity, Earth Planet. Sci. Lett., 244, 251269.

Brousse, R., Barsczus, H., Bellon, H., Cantagrel, J., Diraison, C., Guillou, H., \& Léotot, C.(1990). Les Marquises (Polynésie française); volcanologie, géochronologie, discussion d'un modèle de point chaud. Bull. Soc. Géol. France, 6, 933-949.

Caress, D., \& Chayes, D. (1995). New software for processing data from side-scancapable multibeam sonars. In Oceans' 95: Challenges of our changing global environment, 2, $997-$ 1000, Washington DC, NY, USA: MTS-IEEE.

Clouard V. (2001). Etude géodynamique et structurale du volcanisme de la Polynésie française de 84 Ma à l'actuel, Thèse de l'Université de la Polynésie Française, 214 p.

Clouard, V., \& Bonneville, A. (2001). How many Pacific hotspots are fed by deep mantle plumes? Geology, 695-698.

Clouard, V., \&. Bonneville, A. (2005), Ages of seamounts, islands and plateaus on the Pacific plate, in Plates, Plumes, and Paradigms, edited by G. R. Foulger et al., Geol. Soc. Am. Bull., 388, 71-90, doi:10.1130/2005.2388(06).

Cochran, J. (1986). Variations in subsidence rates along intermediate and fast spreading midocean ridges. Geophys. J. R. Astr. Soc., 87, 421-454.

Courtillot, V., Davaille, A., Besse, J., \& Stock, J. (2003). Three distinct types of hotspots in the Earth's mantle. Earth Planet. Sci. Lett., 205, 295-308.

Crough, S. (1978). Thermal origin of midplate hotspot swells. Geophys. J. R. Astron. Soc. 55, 451-469.

Crough, S. (1983). Hotspot swells. Ann. Rev. Earth Planet. Sci., 11, 165-193.

Davaille, A. (1999). Simultaneous generation of hotspots and superswells by convection in a heterogeneous planetary mantle. Nature, 402, 756-760.

Davies, G. (1988). Ocean bathymetry and mantle convection. 1. Large scale flow and hotspots, J. Geophys. Res., 93(B9), 10,467-10,480. 
Davies, G. (1999), Dynamic Earth: Plates, Plumes and Mantle Convection, Cambridge Univ. Press, Cambridge, U.K.

Desonie, D., Duncan, R., \& Natland, J. (1993). Temporal and geochemical variabilityc of volcanic products of the Marquesas hotspot. J. Geophys. Res., 98, 1764917665.

Diraison, C. (1991). Le volcanisme aérien des archipels polynésiens de la Société, des Marquises et des Australes-Cook. Unpublished doctoral dissertation, Univ. de Bretagne Occidentale. (413 p.)

Duncan, R., \& McDougall, I. (1974). Migration of volcanism with time in the Marquesas Islands, French Polynesia. Earth Planet. Sci. Lett., 21 (4), 414-420.

Duncan, R., \& McDougall, I. (1976). Linear volcanism in French Polynesia. J. Volcanol. Geotherm. Res., 197-227.

Dziewonski, A.M. \& Anderson D.L. (1981). Preliminary reference Earth model, Phys. Earth Planet. Inter., 25, 297-356.

Farnetani, C. G., and H. Samuel (2005), Beyond the thermal plume paradigm, Geophys. Res. Lett., 32, L07311, doi:10.1029/2005GL022360.

Forte, A. \& Mitrovica J. (2001). Deep-mantle high-viscosity flow and thermochemical structure inferred from seismic and geodynamic data. Nature. 410, 1049-1056.

Foulger, G.R., Natland, J.H., Presnall, D.C., \& D.L. Anderson, D.L. (2005), Plates, Plumes, and Paradigms, edited by G. R. Foulger et al, Geol. Soc. Am. Special Volume 388, pp. 881.

Foulger, G.R. (2010), Plates vs Plumes: A Geological Controversy, Wiley-Blackwell, ISBN 9781-4443-3679-5, pp. 328.

Hager, B. (1984). Subducted slabs and the geoid: Constraints on mantle rheology and flow, J. Geophys. Res., 89, 6003- 6015.

Hillier, J., \& Watts, A. (2004). "Plate-like" subsidence of the East Pacific Rise- South Pacific Superswell system, J. Geophys. Res., 109, B10102, doi:10.1029/2004JB003041.

Hofmann, A. W., \& Hart, S.R. (2007), Another nail in which coffin? Science, 315, 39-40.

Holden J.C. \& Vogt P.R . (1977). Graphic Solution to Problems of Plumacy, EOS Trans., AGU, 56 573-580.

Isse, T., D. Suetsugu D., H. Shiobara H., Sugioka, H., Kanazawa, T., \& Fukao, Y. (2006). Shear wave speed structure beneath the South Pacific superswell using broadband data from ocean floor and islands, Geophys. Res. Lett.,33, L16303, doi:10.1029/ 2006GL026872.

Ito, G., McNutt, M., \& Gibson, R. (1995). Crustal structure of the Tuamotu Plateau, 15oS, implications for its origin. J. Geophys. Res., 100, 8097-8114.

Jordahl, K., McNutt, M., \& Caress, D. (2004), Multiple episodes of volcanism in the Southern Austral Islands: Flexural constraints from bathymetry, seismic reflection, and gravity data, J. Geophys. Res., 109, B06103, doi:10.1029/2003JB002885.

Karato, S.I. (2008), Deformation of Earth Materials: An Introduction to the Rheology of Solid Earth, Cambridge Univ. Press, New York, 2008.

Kumagai, I., Davaille, A., \& Kurita, K. (2007). On the fate of thermally buoyant mantle plumes at density interfaces, Earth Planet. Sci. Lett., 254, 180 - 193, doi:10.1016/ j.epsl.2006.11.029.

Le Bars, M., and A. Davaille (2004), Whole layer convection in a heterogeneous planetary mantle, J. Geophys. Res., 109, B03403, doi:10.1029/2003JB002617. 
Levitt, D., \& Sandwell, D. (1996). Modal depth anomalies from multibeam bathymetry: Is there a South Pacific Superswell? Earth Planet. Sci.Lett., 139, 1-16.

Mammerickx, J., \& Herron, E. (1980). Evidence for two fossil spreading ridges in the southeast Pacific, Geol. Soc. Am. Bull., 91, 263- 271.

Mayes, C., Lawver, L., \& Sandwell, D. (1990). Tectonic history and new isochron chart of the South Pacific. J. Geophys. Res., 95 (B6), 8543-8567.

McNamara, A. K., and S. Zhong (2004). Thermochemical structures within a spherical mantle: Superplumes or piles? J. Geophys. Res., 109, B07402, doi:10.1029/ 2003JB002847.

McNutt, M., \& Fischer, K. (1987). The south Pacific Superswell. Am. Geophys. Union Geophys. Monogr, 43, 25-34.

McNutt, M. (1988), Thermal and mechanical properties of the Cape Verde Rise, J. Geophys. Res., 93, 2784-2794.

McNutt, M., Fischer, K., Kruse, S., \& Natland, J. (1989). The origin of the Marquesas fracture zone ridge and its implication for the nature of hot spots. J. Geophys. Res., 91, 381-393.

McNutt, M., \& Judge, A. (1990). The Superswell and mantle dynamics beneath the south Pacific. Science, 248, 969-975.

McNutt, M., Sichoix, L., \& Bonneville, A. (1996). Modal depths from shipboard bathymetry: There is a South Pacific Superswell, Geophys. Res. Lett., 23, 3397- 3400.

McNutt, M., Caress, D., Reynolds, J., Jordahl, K., \& Duncan, R. (1997). Failure of plume theory to explain midplate volcanism in the Southern Austral Islands, Nature, 389, 479-482.

McNutt, M. (1998). Superswells. Rev. Geophys., 36, 211-244.

McNutt, M., \& Bonneville A. (2000), A shallow, chemical origin for the Marquesas swell, Geochem. Geophys. Geosyst., 1, 1014, doi:10.1029/1999GC000028.

McNutt, M. (2006), Another nail in the plume coffin?, Science, 313, 1394-1395.

Mégnin, C., \& Romanowicz, B. (2000). The three-dimensional shear velocity structure of the mantle from the inversion of body, surface and higher-mode waveforms, Geophys. J. Int.,143, 709-728, doi:10.1046/j.1365-246X.2000.00298.x.

Montagner, J.-P. (2002). Upper mantle low anisotropy channels below Pacific Plate Earth Planet. Sci. Lett., 632, 1-12.

Montelli, R., Nolet, G., Dahlen, F.A. \& Masters, G. (2006), A catalogue of deep mantle plumes: New results from finite frequency tomography, Geochem. Geophys. Geosyst., 7, Q11007, doi:10.1029/2006GC001248.

Morgan, W. J. (1968)., Rises, trenches, great faults, and crustal blocks, J. Geophys. Res., 73(6), 1959-1982.

Morgan, W. (1971). Convection plumes in the lower mantle. Nature, 230, 42-43.

Morgan, W. (1972). Plate motion and deep mantle convection. Geol. Soc. Am. Man., 132, 7-22.

Morgan, W., Rodriguez, \& Darwin. (1978). A second type of Hotspot Island. J. Geophys. Res., $83,5355-5360$.

Norris, A., \& Johnson, R. (1969). Submarine volcanic eruption recently located in the Pacific by SOFAR hydrophones. J. Geophys. Res., 74, 650-664.

Obayashi, M., \& Fukao, Y. (2001). Whole Mantle Tomography with an Automatic Block Parameterization. SSJ meeting, B08. 
Ogawa, M. (2007). Superplumes, plates, and mantle magmatism in two-dimensional numerical models. J. Geophys. Res.,112, B06404, doi:10.1029/2006JB004533. Parmentier, E., Turcotte, D., \& Torrance, K. (1975). Numerical experiments on the structure of mantle plumes. J. Geophys. Res., 80 (32), 4417-4424.

Okal, E., \& Cazenave, A. (1985), A model for the plate tectonic evolution of the east central Pacific based on Seasat investigations. Earth Planet. Sci. Lett., 72, 99-116.

Ritsema, J., \& van Heijst, H.J. (2000)., Seismic imaging of structural heterogeneity in Earth's mantle: Evidence for large-scale mantle flow, Sci. Prog., 83, 243-259.

Schlanger, S., Garcia, M., Keating, B., Naughton, J., Sager, W., Haggerty, J. Philipotts, J., \& Duncan, R. (1984). Geology and geochronology of the Line Islands, J. Geophys. Res., 89, 11,216- 11,272.

Schubert, G., G. Masters, P. Olson, and P. Tackley (2004), Superplumes or plume clusters?, Phys. Earth Planet. Inter., 146, 147-162.

Sichoix, L., Bonneville, A., \& McNutt, M. (1998)., The seafloor swells and superswell in French Polynesia, J. Geophys. Res., 103, 27,123-27,133.

Simmons, N. (2007). Thermochemical structure and dynamics of the African superplume. Geophys. Res. Lett. 34, L02301,doi:10.1029/2006GL028009.

Sleep, N. (1990). Hotspots and mantle plumes: some phenomenology. J. Geophys. Res., 95 (B5), 6715\{6736.

Smith, W., \& Sandwell, D. (1997)., Global sea floor topography from satellite altimetry and ship depth soundings. Science, 277, 1956-1962.

Stöffers P. \& the Scientific Party of cruise SO-65 of F.S.Sonne (1990). Active Pitcairn hotspot found. Mar. Geol., 95, 51-55.

$\mathrm{Su}, \mathrm{W} .$, Woodward, R., et Dziewonski, A. (1992). Joint inversions of travel time and waveform data for the 3-D models of the Earth up to degree 12. Eos Trans., 73, 201-202.

Suetsugu, D., Shiobara, H., Sugioka, H., Barruol, G., Schindele, F., Reymond, D., Bonneville, A., Debayle, E.,. Isse, T., Kanazawa T. \& Fukao Y. (2005). Probing South Pacific mantle plumes with ocean bottom seismographs. Eos Trans. Am. Geophys. Un., 86, 429-435.

Suetsugu, D., Isse, T., Tanaka, S., Obayashi, M., Shiobara, H., Sugioka, H., Kanazawa, T.,. Fukao, Y., Barruol, G., \& D. Reymond., (2009), South Pacific mantle plumes imaged by seismic observation on islands and seafloor, Geochem. Geophys. Geosyst., 10, Q11014, doi:10.1029/2009GC002533. D.L. Turcotte,D.L. \& E.R. Oxburgh,E.R. (1973). Mid-plate tectonics. Nature 244, 337-339.

Takeuchi, N. (2007). Whole mantle SH-velocity model constrained by waveform inversion based on three-dimensional Born kernels. Geophys. J. Int., 169(3), 1153-1163, doi:10.1111/j.1365-246X.2007.03405.x.

Takeuchi, N. (2009). A low-velocity conduit throughout the mantle in the robust component of a tomographic model. Geophys. Res. Lett., 36, L07306, doi:10.1029/2009GL037590.

Talandier, J., \& Okal, E. (1984). The volcano seismic swarms of 1981-1983 in the TahitiMehetia area, French Polynesia. , J. Geophys. Res., 89, 11216-11234.

Tanaka, S., Obayashi, M., Suetsugu, D., Shiobara, H., Sugioka, H., Yoshimitsu, J., Kanazawa, T., Fukao, Y. \&. Barruol, G. (2009a). P wave tomography of the mantle beneath the South Pacific Superswell revealed by joint ocean floor and island broadband 
seismic experiments. Phys. Earth Planet. Inter., 172, 268-277, doi:10.1016/j.pepi. 2008.10.016.

Tanaka, S., Suetsugu, D., Shiobara, H., Sugioka, H., Kanazawa, T., Fukao, Y., Barruol, G., \&. Reymond, D. (2009b). On the vertical extent of the large low shear velocity province beneath the South Pacific Superswell, Geophys. Res. Lett., 36, L07305, doi:10.1029/2009GL037568

Turcotte, D.L. \& E.R. Oxburgh, E.R. (1973). Mid-plate tectonics. Nature 244, 337-339.

Turner, D., \& Jarrard, R. (1982). K-Ar dating of the Cook-Austral island chain : A test of the hot-spot hypothesis. J. Volcanol. Geotherm. Res., 12, 187-220.

Van Wykhouse, R. (1973). SYNBAPS, Tech. Rep. TR-233, Natl. Oceanogr. Off., Washington, D. C.

Vidal, V., \& Bonneville, A. ( 2004). Variations of the Hawaiian hot spot activity revealed by variations in the magma production rate. J. Geophys. Res. 109, B03104. doi:10.1029/2003JB002559.

Watts, A., Parsons B., \& Roufosse M. (1985). The relationship between gravity and bathymetry in the Pacific Ocean, Geophys. J. R. Astron. Soc., 83, 263- 298.

White, W., \& Duncan, R. (1996). Geochemistry and geochronology of the Society Islands : New evidence for deep mantle recycling. Am. Geophys. Union Geophys. Monogr, 95, 183-206.

Wilson, J. T. (1963). A possible origin of the Hawaiian Islands. Canadian J. Phys., 41,863-870.

Wolfe, C., McNutt, M., \& Detrick, R. (1994). The Marquesas archipelagic apron: Seismic stratigraphy and implications for volcano growth, mass wasting, and crustal underplating. J. Geophys. Res., 99 (B7), 13591-13608.

Yoshida, M., (2008), Core-mantle boundary topography estimated from numerical simulations of instantaneous mantle flow, Geochem. Geophys. Geosyst., 9, Q07002, doi:10.1029/2008GC002008.

Zhao, D. (2004). Global tomographic images of mantle plumes and suducting slabs: insight into deep earth dynamics. Earth Planet. Sci. Lett., 146, 3-34. 


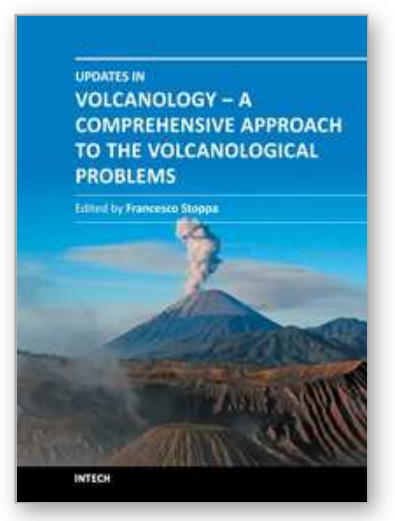

\section{Updates in Volcanology - A Comprehensive Approach to Volcanological Problems}

Edited by Prof. Francesco Stoppa

ISBN 978-953-307-434-4

Hard cover, 242 pages

Publisher InTech

Published online 13, January, 2012

Published in print edition January, 2012

This book ranges from the geologic-petrologic description of world-wide major volcanic fields unfamiliar to international literature, to the discussion and interpretation of the results in light of geophysical techniques. It focuses on several situations that represent large-scale volcanism on Earth, related both with intra-plate or active margins. Many large volcanic complexes of Easter countries are presented, including Japan, Siberian Russia, and Mongolia. A detailed account of the European volcanic province of the Pannonia basin and Central-Southern Spain is given. Southern hemisphere areas of Antarctica and Polynesia are considered as well. The chapters are very informative for those who wish for a guide to visiting, or are curious about main characteristics of the above volcanic areas, some of which are remote and not easily accessible.

\section{How to reference}

In order to correctly reference this scholarly work, feel free to copy and paste the following:

Claudia Adam (2012). Hotspot Concept: The French Polynesia Complexity, Updates in Volcanology - A Comprehensive Approach to Volcanological Problems, Prof. Francesco Stoppa (Ed.), ISBN: 978-953-307-4344, InTech, Available from: http://www.intechopen.com/books/updates-in-volcanology-a-comprehensiveapproach-to-volcanological-problems/hotspot-concept-the-french-polynesia-complexity

\section{INTECH}

open science | open minds

\section{InTech Europe}

University Campus STeP Ri

Slavka Krautzeka 83/A

51000 Rijeka, Croatia

Phone: +385 (51) 770447

Fax: +385 (51) 686166

www.intechopen.com

\section{InTech China}

Unit 405, Office Block, Hotel Equatorial Shanghai

No.65, Yan An Road (West), Shanghai, 200040, China

中国上海市延安西路65号上海国际贵都大饭店办公楼 405 单元

Phone: +86-21-62489820

Fax: +86-21-62489821 
(C) 2012 The Author(s). Licensee IntechOpen. This is an open access article distributed under the terms of the Creative Commons Attribution 3.0 License, which permits unrestricted use, distribution, and reproduction in any medium, provided the original work is properly cited. 